Article

\title{
The Impact of Haze on the Availability of Company Debt Financing: Evidence for Sustainability of Chinese Listed Companies
}

\author{
Bin $\mathrm{Li}^{1}{ }^{1}$, Peixiang Guo ${ }^{2}$ and Yating Zeng ${ }^{1, *}$ \\ 1 School of Economics and Management, Beijing University of Chemical Technology, Beijing 100029, China; \\ libin@mail.buct.edu.cn \\ 2 School of Agricultural Economics and Rural Development, Renmin University of China, \\ Beijing 100872, China; guopeixiang@ruc.edu.cn \\ * Correspondence: zengyating@mail.buct.edu.cn
}

Received: 26 December 2018; Accepted: 30 January 2019; Published: 3 February 2019

check for updates

\begin{abstract}
Based on the data of A-share listed companies in Shanghai and Shenzhen Stock Exchanges from 2013 to 2017 and the air quality monitoring data released by China Environmental Monitoring Station, the paper examines the impact of haze on the availability of company debt financing by using fixed-effects model and quantile regression model. The empirical results show that: Firstly, haze has a positive impact on the demand of company debt financing, and the positive effect is marginal increment. Secondly, haze has a negative impact on the availability of company debt financing, and the negative impact is also marginal increment. Further study found that heavy polluting industry characteristics weaken the impact of haze on company debt financing availability. The paper analyzes the influence of air pollution on enterprise management from the perspective of company debt financing and explains the necessity for companies to implement an environmentally sustainable development strategy.
\end{abstract}

Keywords: haze; listed company; sustainability; availability of debt financing; demand of debt financing.

\section{Introduction}

Debt financing refers to the integration of funds through loans or bond issuance by banks or non-bank financial institutions. It is the most important source of capital for companies. In terms of the ratio of bank credit to GDP, China's ratio is much higher than other countries in the world. Debt financing capacity and availability plays an important role in the sustainable development of Chinese companies. Therefore, Chinese academic circles have been paying great attention to the debt financing of companies to realize the financial sustainability of companies.

In recent years, the environmental problems in China's economic development are becoming much more serious, especially the problem of haze pollution is particularly prominent. Haze is a kind of air pollution weather that occurs when a large amount of fine particles $\left(\mathrm{PM}_{2.5}\right)$ are discharged by economic and social activities of high-density population, which exceed the atmospheric circulation capacity and carrying capacity, resulting in the continuous accumulation of fine particle concentration, and at the same time, effected by static and stable weather [1,2]. Haze not only reduces atmospheric visibility, but also damages people's physical and mental health [3,4], thus also affecting the production and operation of companies. "Haze" and a series of pollution problems, which has associated with the extensive economic growth pattern, are increasingly valued by the public and they require policy makers to take measures $[5,6]$. Under the circumstance, the Chinese government began to put haze 
control work on the agenda, the slogan of "resolutely fight a good defense of the blue sky" has been included in "Report on the work of government on 5 March 2017". After that, the requirements of green and sustainable development for companies have been put forward.

Thus, the haze problem has an impact on the development of companies. The focus of relevant research is mainly on two aspects, one of which focuses on the current situation, causes harm to the human body of haze pollution $[7,8]$. Second, attention is paid to the impact of haze pollution on the production of companies $[9,10]$. In recent years, more and more studies have concluded that haze has an impact on the financial situation of companies. For example, some scholars have analyzed the impact of haze on corporate earnings management [11], on corporate debt financing behavior [12,13]. However, so far, there has been less research focus on the impact of haze on company debt financing, and few scholars have directly used regional haze data to observe the impact of haze pollution levels on the availability of company debt financing.

The increase in haze leads to an increase in the political and environmental costs of companies, and what is more, the poor development of the real economy in recent years in China, the companies have low operating efficiency and a wide gap in the internal funding; the demand of company debt financing has increased. Due to the emphasis on environmental protection of government and the introduction of bank green credit, regional haze has increased the demand of debt financing for companies, but the availability of debt financing has decreased, especially for heavy polluting companies. According to the "Guidelines for the Classification of Listed Companies" issued by the CSRC in 2012, the heavy polluting companies mainly include eight classes, namely extractive industry, food and beverage industry, paper and printing industry, textile and garment fur industry, petrochemical plastics industry, metal and non-metal industry, pharmaceutical biological products industry and water and electricity gas industry. Due to the greater environmental risks, the financing difficulties is more obvious for heavy polluting companies. Based on the 7637 data from A-share listed companies in the Shanghai and Shenzhen Stock Exchanges of China and air quality monitoring data issued by China Environmental Monitoring Station from 2013 to 2017, the paper studies the impact of haze pollution on the availability of company debt financing, and puts forward three hypotheses. Firstly, haze has a positive impact on the demand of company debt financing and the positive effect is marginal increment. Secondly, haze has a negative impact on company debt financing availability, and the negative impact is also marginal increment. Thirdly, heavy pollution industry weakens the impact of haze on company debt financing availability.

The conclusions of the paper mobilize the enthusiasm of companies to participate in haze governance to a certain extent, and reveal the necessity of financial institutions attaching importance to environmental protection and implementing green credit policies, which provide policy-making basis for economic sustainable development and environmental conservation. Compared with the existing literature, the incremental contribution of the paper is concluded as follows. Firstly, by using the air quality monitoring data released by China Environmental Monitoring Station, the paper captures the impact of haze on the availability of company debt financing with the natural environmental change from a dynamic and continuous perspective, and reveals the impact of haze pollution on the availability of company debt financing in specific areas. Secondly, previous studies have mainly studied the impact of haze on heavy polluting companies. While the sample of heavy polluting companies is more typical to reveal the impact of haze, the haze pollution will not only affect heavy polluting companies, but also affect other non-heavy polluting companies. Therefore, full sample data including heavy polluting companies that are used to explore impact of haze on the availability of company debt financing is necessary, which is more representative and the conclusion is more general. Thirdly, the paper finds that haze has a negative impact on the availability of company debt financing, and the negative impact is marginal increment. The study can inspire the enthusiasm of companies to implement environmental sustainable development strategies and make financial institutions realize the optimal allocation of financial resources. 
The rest of the paper is organized as follows: Section 2 reviews the relevant literature of haze and company debt financing and develops three hypotheses. Section 3 constructs the empirical model of haze affecting the availability of company debt financing. Section 4 describes the data sources and sample selection process. Section 5 reports the empirical results of model estimation. Section 6 is the robustness test and Section 7 concludes our research results and reveals the policy implications.

\section{Literature Review and Hypothesis}

\subsection{The Impact of Haze on the Demand of Company Debt Financing}

Previous studies have shown that haze can have a direct impact on people's behavior and health as well as the production and operation activities of companies. In terms of human behavior and health, haze will endanger human's physical and mental health [14-19]. On the one hand, haze can cause lung problems, cardiovascular diseases, metabolic syndrome, and other health problems [20-23]. On the other hand, it can lead to mental symptoms, including anxiety, irritability, emotional disorders and behavioral changes [24], and significantly increase the risk of depression and other diseases, thus endangering people's mental health [25]. Moreover, long-term exposure to a polluted environment will shorten people's life expectancy. Research based on U.S. data found that if $\mathrm{PM}_{2.5}$ increased by 10 micrograms per cubic meter, total mortality, cardiopulmonary mortality, and cancer mortality increased by $4 \%, 6 \%$, and $8 \%$, respectively [26]. In addition, haze also affects the production and operation activities of companies and economic development. Because haze increases the cost of pollution control $[16,19,27-29]$, it has a direct impact on the business behavior of companies, and negatively affects or even offsets the positive welfare brought about by economic development [30]. Liu (2016) [13] found that the equity financing of heavy polluting companies has not decreased, but debt financing has decreased and higher debt costs have been paid after the "PM2.5 explosion" incident based on the data of heavy polluting listed companies. Sheng et al. (2017) [12] found that "PM2.5 explosion" incident had a negative net effect on the financing capacity of heavy polluting companies. In the process of haze control, the level of environmental information disclosure is required to be raised, and the cost of disclosure increases [2,31]. With regard to the causes of haze, it has been studied that the main cause is caused by human factors such as automobile exhaust emissions and the burning of fossil fuels $[7,8,32,33]$, while pollution in other areas, such as in the neighbors, can also lead to haze [34-37]. Additionally, these human activities cannot stop immediately in the short term, so the impact of haze on people's productive lives will be continuous.

At the same time, serious haze pollution has also aroused the attention of public and medias, which not only puts a lot of pressure on companies directly, but also force the authorities to implement strict control, including the formulation of laws and policies, real-time supervision, closure of orders, huge penalties, criminal law, and so on, resulting in the increase in political costs after the implementation of the environmental protection law [11,12]. Environmental cost refers to the total outflow of all economic benefits related to energy conservation and emission reduction, environmental pollution and damage, environmental protection and governance [38] during the product life cycle of a company with the goal of sustainable development. Environmental management (EM) and company social responsibility (CSR) are generally regarded as the commitment of companies to take moral action. However, the short-term cost-effectiveness of environmental governance will not be highlighted because of the large financial, time, and resource costs involved, so environmental management (EM) and company social responsibility (CSR) practices are generally considered expensive [39-42].

After the implementation of the Environmental Protection Law of the People's Republic of China in 2015, all of the companies in manufacturing were required to install clean environmental protection equipment and sewage treatment equipment, policy control in areas with high environmental pollution will be more stringent, which increased the pressure on environmental protection expenditure of companies. With the increase of policy requirements for company disclosure, the cost of environmental protection information disclosure is also increasing year by year. In addition, in order to improve the 
environment in an area, the polluting companies need to change production, relocate, or even close down in accordance with relevant regulations. In some places, companies that exceed the standard and discharge pollutants in excess of the total amount face the risk of shouldering high environmental protection taxes. Company environmental protection and haze control have been intensified [43]. In addition, in recent years, the real economy has not developed smoothly, the operating efficiency is low, the income of companies is not enough, and the internal capital gap is very large. The imperfection of the capital market makes it difficult for companies to obtain equity financing, so the demand of debt financing for companies presents a marginal increasing effect. Accordingly, our first hypothesis is described as follows:

Hypothesis 1. Haze has a positive effect on the demand of company debt financing, and the positive effect is marginal increment.

\subsection{The Impact of Haze on the Availability of Company Debt Financing}

Debt financing has always been the most important source of capital for companies. Especially in developing countries, credit constraints in formal financial markets caused by imperfect capital markets are a universal problem [44]. The scarcity of funds determines the dominant position of financial institutions in credit contracts. Whether an enterprise can obtain loans from the formal financial market and the cost of loans depend on the subjective evaluation of the credit status of a particular borrower by financial institutions [45]. Due to the information asymmetry between the borrowers and the lenders in the credit contract, which leads to adverse selection and moral hazard, the formal financial institutions adopt the credit rationing policy to reduce their own credit risk [46], that is, financial institutions often treat companies differently through differential degrees of credit restraint $[47,48]$. As it is not only time-consuming, but also expensive for financial institutions build to be fully independent information collection system to identify the risks of companies, so in the credit decision-making process, it is mainly based on the financial information provided by companies and the supporting information of third parties to carry out credit rating to companies. The information provided by the companies to the financial institution mainly reflects the financial situation of the companies, the operating results and the cash flow finance information. Usually the better the financial performance of a company, the higher the credit rating, the easier it is to get loans [49]. Third-party supporting information includes audit opinions, social evaluation, environmental assessment, and so on. With the attention of the whole society to environmental issues and the implementation of the "green credit" policy, financial institutions are also increasingly valuing the environmental performance of enterprises when conducting credit assessments of companies.

The availability of company debt financing is the proportion of true debt financing that the company actually obtains in the case of the debt demand of the company. For companies with greater risks, financial institutions usually adopt a credit restriction policy. As the haze worsens, public voices increase, the medias begin to report and the government imposes an environmental tax, so financial institutions in the credit assessment expect that polluting companies might face high environmental compensation costs [9], capital costs [50], and environmental liability liabilities [51], which are associated with higher operational risk in the future [10].

Therefore, with the increase of haze, the financing demand of companies is increasing, while the amount of financing acquisition is difficult to improve, the financing availability of companies will decline. Additionally, with the increasing of the haze, the demand of debt financing increases more and more rapidly, the negative impact on the availability of debt financing will also increase. Based on the above analysis, our second hypothesis is described as follows:

Hypothesis 2. Haze has a negative impact on the availability of company debt financing, and the negative impact is marginal increment. 


\subsection{Moderating Effect of Heavy Polluting Industries}

Industrial production of the company is the culprit and main responsible person of haze, especially heavy polluting companies. Based on the perspective of public pressure, people's awareness of environmental protection is growing, and social media begins to pay close attention to environmental pollution and environmental protection. At the same time, environmental supervision departments have also made positive guidance to the environmental protection of companies. Environmental protection has become a widely recognized stable and influential social norms by social members [52,53]. So that, companies in polluted areas are more vulnerable to external attention and regulation. For the companies in crisis, they suffer tremendous pressure from public opinion, are condemned by members of the community, and are more vulnerable to public supervision and market discipline. Firstly, some of the sanctions will come from the regulatory authorities. When heavy polluting companies apply for refinancing, they will be strictly supervised and restricted by the government due to increased public pressure. Financial institutions will be more cautious about refinancing heavy polluting companies. From another side, public opinion and media coverage caused by environmental pollution have increased, and these negative signals are transmitted to financial institutions, affecting their decision-making. Therefore, we expect that, as public pressure increases, the financing of companies with severe haze in the region will be greatly limited and debt financing will be reduced.

In recent years, banks have introduced a "green-credit-policy", which takes compliance with environmental testing standards, pollution control effects and ecological protection as an important prerequisite for credit approval. Green credit is often referred to as Sustainable Finance or Environmental Finance. The financial institution can guide capital-oriented industries and companies in favor of environmental protection through differential pricing, which can effectively promote sustainable development. At the same time, it strengthens the financial ability of the institutions to control risks, create conditions to actively promote green credit, and it is also conducive to get rid of the shadow of "bad debts" and "dead debts", which have been puzzled for a long time in the past, thus improving the operational performance of commercial banks [54]. Environmental protection information has become an important factor for financial institutions to assess the risks of companies or projects, especially in heavy polluting industries [55]. During the haze generation period, heavy polluting companies face a large amount of environmental costs, including the cost of purchasing environmental protection facilities, the cost of cleaning emissions, the cost of improving production processes and other environmental control costs, which results in cash outflow [56], thus the credit rating of financial institution for heavy polluting companies has declined, reducing the credit for heavy polluting companies. Based on the above analysis, the third hypothesis is described as follows:

Hypothesis 3. The characteristics of heavy pollution industries have a negative moderating effect on the relationship between haze and company debt financing availability.

\section{Model}

In order to test the effect of haze on the availability of company debt financing, the paper establishes the following four multiple regression models. Among them, model (1) is used to test the relationship between haze and the demand of company debt financing, and the model (2) is used to test the relationship between haze and the availability of company debt financing. Model (3) and model (4) add intersection items of haze and whether it is polluting companies (PM2.5 $5_{\mathrm{it}}{ }^{*}$ POLLUTE $_{\mathrm{it}}$ ) to test the moderating effect of heavy polluting industry characteristics on the relationship between haze and the availability of company debt financing.

$$
\text { IFTG_ASSET }{ }_{\text {it }}=\alpha_{0}+\alpha_{1} \text { PM2. } 5_{\text {it }}+\sum_{\mathrm{k}=2}^{15} \alpha_{\mathrm{k}} \mathrm{CV}_{\mathrm{kit}}+\sum \mathrm{YEAR}+\sum \mathrm{INDU}+\sum \mathrm{CITY}+\varepsilon
$$




$$
\begin{aligned}
& \text { LOAN_AVAIL } L_{i t}=\alpha_{0}+\alpha_{1} \text { PM2.5 } 5_{\text {it }}+\sum_{\mathrm{k}=2}^{15} \alpha_{\mathrm{k}} \mathrm{CV}_{\mathrm{kit}}+\sum \mathrm{YEAR}+\sum \mathrm{INDU}+\sum \mathrm{CITY}+\varepsilon \\
& \text { IFTG_ASSET }_{\text {it }}=\alpha_{0}+\alpha_{1} \text { PM2. } 5_{\text {it }}+\alpha_{2} \text { PM2.5 } \text { it }_{*} * \text { POLLUTE }_{i t}+\sum_{\mathrm{k}=3}^{16} \alpha_{\mathrm{k}} \mathrm{CV}_{\mathrm{kit}} \\
& +\sum \mathrm{YEAR}+\sum \mathrm{INDU}+\sum \mathrm{CITY}+\varepsilon \\
& \text { LOAN_AVAIL }{ }_{i t}=\alpha_{0}+\alpha_{1} \text { PM2. } 5_{i t}+\alpha_{2} \text { PM2. } 5_{i t} * \text { POLLUTE }_{i t}+\sum_{\mathrm{k}=3}^{16} \alpha_{\mathrm{k}} \mathrm{CV}_{\mathrm{kit}} \\
& +\sum \mathrm{YEAR}+\sum \mathrm{INDU}+\sum \mathrm{CITY}+\varepsilon
\end{aligned}
$$

where, there are two dependent variables, they are demand of company debt financing (IFTG_ASSET $\mathrm{it}_{\mathrm{it}}$ ) and availability of company debt financing (LOAN_AVAIL ${ }_{i t}$ ). Among them, the demand of company debt financing (IFTG_ASSET ${ }_{\text {it }}$ ) is expressed as (cash dividend paid + working capital increase + capital expenditure - cash flow of after-tax business activities) / total assets at the end of the year [57-59]. In order to reflect the level of credit constraints faced by enterprises, the availability of company debt financing (LOAN_AVAIL $L_{i t}$ ) is the total scale of the loan that a company obtains divided by the demand of company debt financing. Among them, the total scale of loan is calculated by (short-term bank loans at the end of the year + long-term loans due one year at the end of the year + long-term bank loans at the end of the year). The independent variable is haze (PM2. $5_{\mathrm{it}}$ ), which is based on the air quality monitoring data released by China Environmental Monitoring Station.

In order to reduce the impact of other factors, 13 control variables are selected. Where $\mathrm{CV}_{\mathrm{kit}}$ is the control variable of company $i$ in the fiscal year $t$. Among them, the paper takes SIZE $_{i t}$ as the control variable in order to eliminate the impact of the company's scale on company performance, which is the logarithm of the total assets of the company. GROW $\mathrm{it}_{\mathrm{it}}$ is the growth of the company $i$ in the fiscal year $t$. Companies with better growth are more likely to be trapped. There are tight financial chain conditions and high financial distress costs. The growth rate of business income $\mathrm{REV}_{\text {it }}$ indicates the profitability of the company, which is represented by the nature logarithm of the revenue items in the income statement. $\mathrm{ROA}_{i t}$ is the asset profitability of the company $i$ in the fiscal year $t$, and the companies with stronger profitability have stronger incentives to use the tax shield of the debt [16]. QUIC $_{\text {it }}$ indicates internal liquidity as the quick ratio, a better liquidity, a faster company cash flow, and less demand for external funds. STATE ${ }_{i t}$ is the property right nature of the company $i$ in the fiscal year $t$. In terms of internal governance variables, the paper also selects five typical control variables, they are ownership concentration (TOP10 $0_{\mathrm{it}}$ ), number of independent directors (INDE $\mathrm{it}_{\mathrm{it}}$ ), CEO duality (DIR_CEO $\left.{ }_{i t}\right)$, executive compensation $\left(\mathrm{EXCP}_{\mathrm{it}}\right)$, and executive shareholding ratio $\left(\mathrm{MGT}_{\mathrm{it}}\right)$. In addition, the control variables to enter the model include industry dummy variables, year dummy variables, and city dummy variables.

The fixed-effects regression model is used to estimate the models (1) to (4). However, the fixed-effects regression model can only estimate the average influence of each factor on the dependent variable, but it is not possible to analyze the distribution law of the influence of each factor on the availability of company debt financing. The quantile regression model which proposed by Koenker and Bassett in 1978 can solve this problem. The quantile regression model can analyze the influence of independent variables on dependent variable at different quantile points, so the analysis results will be more comprehensive and in-depth. In order to investigate the influence of haze on the availability of company debt financing at different quantiles, the quantile regression model is further used to test models (1) to (4).

Finally, we use the sample data of listed companies in China to estimate models (1) to (4) and observe the directions and significance of the coefficients of $\alpha$. All the Variables are defined in Table 1. 
Table 1. Variable definition.

\begin{tabular}{|c|c|}
\hline Variable & Description \\
\hline IFTG_ASSET $_{\text {it }}$ & $\begin{array}{l}\text { The demand of company debt financing, which can be calculated as: (cash dividend } \\
\text { payment + capital expenditure + net increase in working capital - cash flow from } \\
\text { operating activities after tax)/total assets at the end of the year. }\end{array}$ \\
\hline LOAN_AVAIL & $\begin{array}{l}\text { The availability of debt financing, which equals the scale of company debt financing/the } \\
\text { demand of company debt financing, where the scale of company debt financing can be } \\
\text { calculated as (short-term bank borrowings at the end of the year + long-term bank } \\
\text { borrowings due within one year at the end of the year + long-term bank borrowings at the } \\
\text { end of the year). }\end{array}$ \\
\hline PM2.5 $5_{\text {it }}$ & $\begin{array}{l}\text { Haze, which equals } \mathrm{PM}_{2.5} \text { air quality monitoring data released by China Environmental } \\
\text { Monitoring Station. }\end{array}$ \\
\hline POLLUTE $_{\text {it }}$ & A dummy variable, which equals 1 if it is a high polluting companies, 0 otherwise. \\
\hline $\mathrm{SIZE}_{\mathrm{it}}$ & Size, which equals the natural logarithm of the total assets at the end of the year. \\
\hline GROW $_{\text {it }}$ & Amount of increased revenue in current year/total amount of revenue in last year. \\
\hline $\mathrm{REV}_{\text {it }}$ & Revenue, which equals the natural logarithm of total revenue in the profit statement. \\
\hline $\mathrm{ROA}_{\mathrm{it}}$ & Return of asset, which equals total profit/total assets. \\
\hline $\mathrm{QUIC}_{\mathrm{it}}$ & $\begin{array}{l}\text { Quick ratio, which equals the difference between current assets and inventory divided by } \\
\text { current liabilities. }\end{array}$ \\
\hline DEBT_RATIO ${ }_{\text {it }}$ & Debt asset ratio, which equals average total liabilities/average total assets. \\
\hline STATE $_{\text {it }}$ & A dummy variable, which equals 1 if it is state-owned companies and 0 otherwise. \\
\hline $\mathrm{TOP}_{10} \mathrm{it}_{\mathrm{H}}$ & $\begin{array}{l}\text { Equity concentration, which is the sum of the shareholdings of the top } 10 \text { largest } \\
\text { shareholders. }\end{array}$ \\
\hline $\mathrm{INDE}_{\mathrm{it}}$ & Number of independent directors. \\
\hline DIR_CEO & A dummy variable, which equals 1 if the two positions are separated and 0 otherwise. \\
\hline $\mathrm{EXCP}_{\text {it }}$ & $\begin{array}{l}\text { Manager salary, which is the natural logarithm of the top three remuneration figures } \\
\text { of executives. }\end{array}$ \\
\hline $\mathrm{MGT}_{\text {it }}$ & Executive shareholding ratio, which is the ratio of executive ownership to total equity. \\
\hline GDP_DIV $_{\text {it }}$ & Regional GDP, which is the natural logarithm of city GDP. \\
\hline $\mathrm{YEAR}_{\mathrm{it}}$ & $\begin{array}{l}\text { A dummy variable, which equals } 1 \text { when the company belongs to the year } t \text {, and } \\
0 \text { otherwise. }\end{array}$ \\
\hline $\mathrm{INDU}_{\text {it }}$ & $\begin{array}{l}\text { A dummy variable, which equals } 1 \text { when the company belongs to industry } m \text {, and } \\
0 \text { otherwise. }\end{array}$ \\
\hline CITY $_{\text {it }}$ & A dummy variable, which equals 1 when the company belongs to city $n$, and 0 otherwise. \\
\hline
\end{tabular}

\section{Data}

\subsection{Sample Selection}

The sample of the paper is A-share listed companies in the stock markets of Shanghai and Shenzhen Stock Exchange in China from 2013 to 2017. The financial statements data of listed companies is derived from Chinese Stock Market and Accounting Research Database (CSMAR). CSMAR databases are widely used in Chinese accounting research, like COMPUSTAT/CRSP in the US [60], and the haze pollution data are from the air quality monthly reports of 74 cities in China from 2013 to 2017 issued by China Environmental Monitoring Station. Due to the impact of the "PM 2.5 explosion" incident in 2012, under the pressure of strong public opinion, the Chinese government began to attach importance to haze monitoring and control work. As the China Environmental Monitoring Station began to disclose air pollution monitoring data in 2013, the sample range of this paper began in 2013. The initial sample consists of 18204 annual records of companies. After excluding the listed companies in the financial sector, ST (Special Treatment) companies, the listed companies in which the air pollution data were not disclosed and the listed companies whose relevant variables were missing. The final sample consists of 7637 observations. The sample selection process is shown in Table 2. At the same time, in order to eliminate the interference of outliers, all continuous variables are winsorized at the level of $1 \%$. The data are processed by SPSS20 and Stata12.0. 
Table 2. Sample selection process.

\begin{tabular}{lc}
\hline \multicolumn{1}{c}{ Sampling Procedure } & Observations \\
\hline All observations from 2013 to 2017 & 18204 \\
Less observations of B share companies & $(434)$ \\
Less financial and insurance industry & $(245)$ \\
Less observations of ST companies & $(344)$ \\
Less observations with missing air quality monitoring data & $(4089)$ \\
Less observations with missing and duplicate data, outliers & $(3914)$ \\
Tail processing & $(1541)$ \\
Observations in the final sample & 7637 \\
\hline
\end{tabular}

\subsection{Descriptive Statistics}

Table 3 reports descriptive statistics of relevant variables of listed companies. From Table 3, we can see that the minimum value of debt financing demand (IFTG_ASSET ${ }_{\text {it }}$ ) is -5.910 , the maximum value is 11.486 , the mean value is 9.014 , the mean value is greater than 0 , which shows that there is an internal financing gap in China's companies as a whole and there is a large financing demand in most companies. The mean value of availability of company debt financing (LOAN_AVAIL $L_{i t}$ ) is 0.135 , which shows that overall debt financing demand of companies are greater than the loans they receive from financial institutions. The standard deviation is 13.392, which shows that the availability of company debt financing varies greatly among companies. The minimum value of haze (PM2.5 $5_{\text {it }}$ ) is 20.083, the maximum value is 160.070 , the mean value is 54.636 , which shows that the overall air pollution in China is in the state of light pollution. The average value of heavy polluting industries (POLLUTE $\left.{ }_{i t}\right)$ is 0.151 , which indicates that the heavy polluting industry accounts for $15 \%$ of the entire industry.

Table 3. Descriptive statistics.

\begin{tabular}{cccccc}
\hline Variable & $\mathbf{N}$ & Mean & Std. Dev. & Min & Max \\
\hline IFTG_ASSET $_{\text {it }}$ & 7637 & 9.014 & 0.597 & -5.910 & 11.486 \\
LOAN_AVAIL $_{\text {it }}$ & 7637 & 0.135 & 13.392 & -265.037 & $1,134.350$ \\
PM2.5i & 7637 & 55.975 & 20.757 & 20.083 & 160.070 \\
POLLUTE $_{\text {it }}$ & 7637 & 0.151 & 0.358 & 0.000 & 1.000 \\
SIZE $_{\text {it }}$ & 7637 & 9.729 & 0.580 & 7.503 & 12.381 \\
GROW $_{\text {it }}$ & 7637 & 9.184 & 675.366 & -10.161 & $59,411.550$ \\
REV $_{\text {it }}$ & 7637 & 9.394 & 0.683 & 0.000 & 12.459 \\
ROA $_{\text {it }}$ & 7637 & 0.244 & 1.063 & -0.928 & 41.462 \\
QUIC $_{\text {it }}$ & 7637 & 1.495 & 1.699 & 0.000 & 35.787 \\
DEBT RATIO $_{\text {it }}$ & 7637 & 0.482 & 0.757 & 0.038 & 63.971 \\
STATE $_{i t}$ & 7637 & 0.416 & 0.493 & 0.000 & 1.000 \\
TOP10 $_{\text {it }}$ & 7637 & 1.738 & 0.130 & 1.094 & 2.005 \\
INDE $_{\text {it }}$ & 7637 & 3.208 & 0.601 & 0.000 & 7.000 \\
DIR_CEO $_{\text {it }}$ & 7637 & 1.733 & 0.471 & 0.000 & 2.000 \\
EXCP $_{i t}$ & 7637 & 6.242 & 0.372 & 0.000 & 7.560 \\
MGT $_{\text {it }}$ & 7637 & 0.059 & 0.129 & 0.000 & 1.095 \\
GDP_DIV $_{\text {it }}$ & 7637 & 5.511 & 0.730 & 0.000 & 5.918 \\
\hline
\end{tabular}

\subsection{Correlation Analysis}

In the Pearson correlation coefficient and Spearman correlation coefficient of the variables, the correlation coefficients of all independent variables and control variables are less than 0.5 (excluding autocorrelation). What is more, from Table 4, we can also see that PM2.5 it and IFTG_ASSETit are significantly positively correlated, PM2.5 $5_{\text {it }}$ and LOAN_AVAIL ${ }_{i t}$ are significantly negatively correlated, preliminarily confirming the previous conjecture of the relationship between variables. Further research finds that variance inflation factors (VIF) are all less than two, and the mean value is 1.149. There is no serious multicollinearity problem for the model. 
Table 4. Variance inflation factors test.

\begin{tabular}{ccc}
\hline Variable & VIF & 1/VIF \\
\hline MGT $_{\text {it }}$ & 1.410 & 0.710 \\
STATE $_{\text {it }}$ & 1.360 & 0.736 \\
DIR_CEO $_{\text {it }}$ & 1.230 & 0.812 \\
EXCP $_{\text {it }}$ & 1.210 & 0.830 \\
REV $_{\text {it }}$ & 1.160 & 0.862 \\
TOP10 $_{\text {it }}$ & 1.150 & 0.867 \\
INDE $_{\text {it }}$ & 1.150 & 0.868 \\
QUIC $_{\text {it }}$ & 1.140 & 0.877 \\
SIZE $_{\text {it }}$ & 1.110 & 0.901 \\
PM2.5 $_{\text {it }}$ & 1.080 & 0.927 \\
GDP_DIV $_{\text {it }}$ & 1.040 & 0.961 \\
ROA $_{\text {it }}$ & 1.030 & 0.967 \\
DEBT RATIO $_{\text {it }}$ & 1.020 & 0.969 \\
GROW $_{\text {it }}$ & 1.000 & 0.999 \\
Mean VIF & \multicolumn{2}{c}{1.149} \\
\hline
\end{tabular}

\section{Empirical Results}

\subsection{The Impact of Haze on Company Debt Financing Demand}

After controlling the impact of year $\left(\mathrm{YEAR}_{\mathrm{it}}\right)$, industry $\left(\mathrm{INDU}_{\mathrm{it}}\right)$, and region $\left(\mathrm{CITY}_{\mathrm{it}}\right)$, the paper uses the fixed-effects model and full-sample data to estimate the model (1) to test the impact of haze pollution on the demand of company debt financing. The results are shown in fixed-effects model of Table 5, the Chi-square statistics with the degree of Hausman test is 219.170, which exceeds the critical value at the $1 \%$ significance level $(P$ Value $=0.000)$. Therefore, we reject the null hypothesis and conclude that the fixed-effects model approach performs. We can see that PM2. $5_{\text {it }}$ is significant positive at $1 \%$ level, and the coefficient is 0.951 , which indicates haze pollution has a positive impact on the demand of company debt financing, and the higher haze pollution, the more demand of company debt financing.

In order to further test the influence of haze on company debt financing demand under the different haze pollution levels, the paper uses the quantile regression model to analyze the influence of haze on debt financing demand at different quantile points, the results are shown in quantile regression model of Table 5. From the regression results, we can first see that at the $30 \%$ quantile level, the P value of coefficient is greater than 0.1 , which indicates that the quantile regression coefficient at the front of conditional distribution is insignificant. The regression coefficients of PM2.5 $5_{\text {it }}$ are all significant positive at the quantile range of $50 \%, 70 \%$, and $90 \%$ level, which indicates that haze has a positive impact on the demand of company debt financing. Secondly, comparing the regression coefficients of PM2.5 it of different quantiles, which are rising steadily from -0.318 to 1.094 . On the $50 \%$ quantile, the regression coefficient of PM2. $5_{\text {it }}$ is 0.090 . On this quantile, each one unit increase of haze will increase the demand of company debt financing by $9 \times 10^{-5}$ unit. The regression coefficient of PM2.5it is 1.094 in the $90 \%$ quantile. At this quantile, the demand of company debt financing will increase $1.094 \times 10^{-3}$ unit for every one unit increase in haze. This shows that there is a marginal increment trend of the positive effect between haze and demand of company debt financing, which confirms $\mathrm{H}_{1}$.

In addition, in the control variables, the regression coefficient of $\mathrm{SIZE}_{\mathrm{it}}$ is significantly positive, indicating that the larger the company size, the greater company debt financing demand. The regression coefficient of $R V_{i t}$ is significantly negative, which indicates total revenue reduces the company debt financing demand. Among the governance variables, the regression coefficients of $\mathrm{INDE}_{i t}$ and STATE $\mathrm{it}_{\mathrm{it}}$ are significantly negative, indicating that debt asset ratio and equity nature reduce the company debt financing demand. The regression coefficient of $\mathrm{TOP} 10_{\text {it }}$ is significantly positive, indicating that the higher the concentration of equity, the greater company debt financing demand. The other variables are not significant in the model, and it is difficult to judge the specific impact effect. 
Table 5. Result of the impact of $\mathrm{PM}_{2.5}$ on demand of company debt financing.

\begin{tabular}{|c|c|c|c|c|c|c|}
\hline \multirow{2}{*}{ IFTG_ASSET $_{\text {it }} \times 1000$} & \multirow{2}{*}{ Fixed-Effects Model } & \multicolumn{5}{|c|}{ Quantile Regression Model } \\
\hline & & QR_10 & QR_30 & QR_50 & QR_70 & QR_90 \\
\hline PM2.5it & $\begin{array}{c}0.951^{* * *} \\
(5.165)\end{array}$ & $\begin{array}{l}-0.318^{* *} \\
(-2.554)\end{array}$ & $\begin{array}{c}-0.038 \\
(-0.840)\end{array}$ & $\begin{array}{c}0.090 * * \\
(2.367)\end{array}$ & $\begin{array}{c}0.232^{* * *} \\
(3.105)\end{array}$ & $\begin{array}{l}1.094^{* * *} \\
(4.584)\end{array}$ \\
\hline SIZE $_{\text {it }}$ & $\begin{array}{c}42.405^{* * *} \\
(3.148)\end{array}$ & $\begin{array}{c}-196.550 \text { *** } \\
(-10.189)\end{array}$ & $\begin{array}{c}23.834^{* * *} \\
(3.871)\end{array}$ & $\begin{array}{c}149.923 * * * \\
(15.106)\end{array}$ & $\begin{array}{c}315.250 * * * \\
(19.249)\end{array}$ & $\begin{array}{c}710.027 * * * \\
(15.568)\end{array}$ \\
\hline $\mathrm{GROW}_{\text {it }}$ & $\begin{array}{c}-0.002 \\
(-0.927) \\
\end{array}$ & $\begin{array}{c}-0.010 \\
(-0.105) \\
\end{array}$ & $\begin{array}{c}-0.017 \\
(-0.056)\end{array}$ & $\begin{array}{c}-0.020 \\
(-0.035) \\
\end{array}$ & $\begin{array}{c}-0.023 \\
(-0.014) \\
\end{array}$ & $\begin{array}{c}-0.034 \\
(-0.024) \\
\end{array}$ \\
\hline $\mathrm{REV}_{\text {it }}$ & $\begin{array}{c}-47.523^{* * *} \\
(-4.875)\end{array}$ & $\begin{array}{c}21.354^{* * *} \\
(2.865)\end{array}$ & $\begin{array}{c}17.744^{* * *} \\
(3.367)\end{array}$ & $\begin{array}{l}3.070 \\
(0.703)\end{array}$ & $\begin{array}{c}-27.108^{* * *} \\
(-2.824)\end{array}$ & $\begin{array}{c}-122.198 \text { *** } \\
(-6.067)\end{array}$ \\
\hline $\mathrm{ROA}_{\mathrm{it}}$ & $\begin{array}{c}2.169 \\
(1.403)\end{array}$ & $\begin{array}{c}11.883^{* * *} \\
(5.055)\end{array}$ & $\begin{array}{c}5.474^{* * *} \\
(2.873)\end{array}$ & $\begin{array}{c}1.745 \\
(0.543)\end{array}$ & $\begin{array}{c}-4.443 \\
(-1.341) \\
\end{array}$ & $\begin{array}{c}-16.275^{* * *} \\
(-3.266)\end{array}$ \\
\hline QUIC $_{\text {it }}$ & $\begin{array}{c}52.285^{* * *} \\
(35.580) \\
\end{array}$ & $\begin{array}{c}1.458 \\
(1.392) \\
\end{array}$ & $\begin{array}{c}14.276 \text { *** } \\
(6.644)\end{array}$ & $\begin{array}{c}23.094 * * * \\
(7.748) \\
\end{array}$ & $\begin{array}{c}26.531 * * * \\
(8.508) \\
\end{array}$ & $\begin{array}{c}41.534^{* * * *} \\
(4.015)\end{array}$ \\
\hline DEBT RATIO $_{\text {it }}$ & $\begin{array}{c}-57.886^{* * *} \\
(-25.356) \\
\end{array}$ & $\begin{array}{c}-196.534 * * * \\
(-7.867)\end{array}$ & $\begin{array}{c}-75.091 \text { *** } \\
(-3.258)\end{array}$ & $\begin{array}{l}-18.642 \\
(-0.646)\end{array}$ & $\begin{array}{c}7.701 \\
(0.329) \\
\end{array}$ & $\begin{array}{c}370.919 * * * \\
(3.835)\end{array}$ \\
\hline STATE $_{\text {it }}$ & $\begin{array}{c}-40.065^{* *} \\
(-2.189) \\
\end{array}$ & $\begin{array}{c}-37.711^{* * *} \\
(-4.282) \\
\end{array}$ & $\begin{array}{c}-22.962 * * * \\
(-8.013) \\
\end{array}$ & $\begin{array}{c}-15.778 * * * \\
(-5.574) \\
\end{array}$ & $\begin{array}{c}-12.596^{* * *} \\
(-3.203)\end{array}$ & $\begin{array}{l}-23.301 \\
(-1.628) \\
\end{array}$ \\
\hline TOP10 $_{\text {it }}$ & $\begin{array}{l}3.150^{* * *} \\
(12.997) \\
\end{array}$ & $\begin{array}{c}-1.399^{* * *} \\
(-5.637)\end{array}$ & $\begin{array}{l}-0.228^{* *} \\
(-2.562)\end{array}$ & $\begin{array}{l}0.164^{*} \\
(1.656)\end{array}$ & $\begin{array}{c}0.566^{* * *} \\
(4.743)\end{array}$ & $\begin{array}{c}2.751^{* * *} \\
(7.066)\end{array}$ \\
\hline $\mathrm{INDE}_{\mathrm{it}}$ & $\begin{array}{c}1.671 \\
(0.306)\end{array}$ & $\begin{array}{c}-24.013 * * * \\
(-3.090)\end{array}$ & $\begin{array}{c}-15.173 \text { *** } \\
(-5.367)\end{array}$ & $\begin{array}{c}-8.207^{* * *} \\
(-2.841)\end{array}$ & $\begin{array}{c}-4.368 \\
(-0.895) \\
\end{array}$ & $\begin{array}{c}35.052 \text { ** } \\
(2.215)\end{array}$ \\
\hline DIR_CEO & $\begin{array}{c}3.275 \\
(0.644) \\
\end{array}$ & $\begin{array}{c}17.436^{* * *} \\
(3.335)\end{array}$ & $\begin{array}{c}-0.168 \\
(-0.085) \\
\end{array}$ & $\begin{array}{l}-3.862 * * \\
(-2.193)\end{array}$ & $\begin{array}{l}-6.775^{* *} \\
(-2.080)\end{array}$ & $\begin{array}{c}-45.760 * * * \\
(-3.500)\end{array}$ \\
\hline $\mathrm{EXCP}_{\text {it }}$ & $\begin{array}{l}10.155 \\
(1.251) \\
\end{array}$ & $\begin{array}{c}95.817^{* * *} \\
(7.762) \\
\end{array}$ & $\begin{array}{c}26.718^{* * *} \\
(5.002) \\
\end{array}$ & $\begin{array}{c}20.831 * * * \\
(3.381) \\
\end{array}$ & $\begin{array}{l}14.042 \\
(1.299) \\
\end{array}$ & $\begin{array}{c}45.850 * * * \\
(2.694) \\
\end{array}$ \\
\hline $\mathrm{MGT}_{\text {it }}$ & $\begin{array}{l}46.173 \\
(1.607)\end{array}$ & $\begin{array}{c}40.897^{* *} \\
(2.498)\end{array}$ & $\begin{array}{l}-11.871^{*} \\
(-1.817)\end{array}$ & $\begin{array}{c}-9.959 \\
(-1.303) \\
\end{array}$ & $\begin{array}{l}-19.405 \\
(-1.570) \\
\end{array}$ & $\begin{array}{c}-102.004^{* * *} \\
(-2.723)\end{array}$ \\
\hline GDP_DIV $_{\text {it }}$ & $\begin{array}{c}5.426 \\
(0.608)\end{array}$ & $\begin{array}{c}35.570 * * \\
(2.432)\end{array}$ & $\begin{array}{c}10.023 * * \\
(2.127)\end{array}$ & $\begin{array}{l}8.839^{*} \\
(1.711)\end{array}$ & $\begin{array}{c}2.563 \\
(0.359)\end{array}$ & $\begin{array}{l}-19.171 \\
(-0.675)\end{array}$ \\
\hline Constant & $\begin{array}{l}-138.868 \\
(-1.263) \\
\end{array}$ & $\begin{array}{c}1016.905^{* * *} \\
\quad(8.665)\end{array}$ & $\begin{array}{c}-496.044^{* * *} \\
(-9.124)\end{array}$ & $\begin{array}{l}-1500 * * * \\
(-23.679) \\
\end{array}$ & $\begin{array}{l}-2800^{* * *} \\
(-24.335) \\
\end{array}$ & $\begin{array}{l}-5900^{* * *} \\
(-17.560) \\
\end{array}$ \\
\hline YEAR $_{\text {it }}$ & control & & & control & & \\
\hline $\mathrm{INDU}_{\text {it }}$ & control & & & control & & \\
\hline $\mathrm{CITY}_{\text {it }}$ & control & & & control & & \\
\hline $\mathrm{N}$ & 7637 & & & 7637 & & \\
\hline adj. $R^{2}$ & 0.102 & 0.077 & 0.027 & 0.057 & 0.115 & 0.213 \\
\hline $\mathrm{F}$ & 194.583 & - & - & - & - & - \\
\hline $\begin{array}{l}\text { Hausman test } \\
\text { (P Valve) }\end{array}$ & $\begin{array}{l}219.17 \\
(0.000)\end{array}$ & - & - & - & - & - \\
\hline
\end{tabular}

After controlling the impact of year $\left(\mathrm{YEAR}_{\mathrm{it}}\right)$, industry $\left(\mathrm{INDU}_{\mathrm{it}}\right)$, and region $\left(\mathrm{CITY}_{\mathrm{it}}\right)$, the paper uses fixed-effects model and full-sample data to estimate the model (2) and tests the impact of haze on the availability of company debt financing. The results are shown in fixed-effects model of Table 6, the Chi-square statistics with degree of Hausman test is 356.25 , which exceeds the critical value at the $1 \%$ significance level $(\mathrm{P}$ Value $=0.000)$. Therefore, we reject the null hypothesis and conclude that the fixed-effects model approach performs. Through the regression results, we can see that the coefficient of PM2.5 it is significantly negative at $5 \%$ level, which indicates that haze pollution has a negative impact on the availability of company debt financing.

In order to further test the influence of haze on company debt financing availability under different haze pollution levels, this paper uses the quantile regression model to analyze the influence of haze on debt financing availability at different quantile points, the results are shown in Table 6. From the regression results, firstly, we can see that the $\mathrm{P}$ value of coefficients are greater than 0.1 at the $10 \%$ and 
$90 \%$ quantile level, which indicates that the quantile regression coefficient at the front of conditional distribution and at the end of conditional distribution are insignificant. The regression coefficients of PM2.5 it are significant negative at the quantile range of 30\%,50\%, and 70\% level, which indicates that haze has a negative impact on the availability of company debt financing. Secondly, comparing the regression coefficients of PM2. $5_{\text {it }}$ of different quantiles, which are rising steadily from -0.937 to -3.097 . On the $30 \%$ quantile, the regression coefficient of PM2. $5_{\text {it }}$ is -0.937 and significant at $5 \%$ level, which means at this quantile, every one unit increase of haze will decrease the availability of company debt financing by $9.47 \times 10^{-4}$ unit. The regression coefficient of PM2. $5_{\text {it }}$ is -3.097 in the $90 \%$ quantile, which means that, at this quantile, the availability of company debt financing will decrease $3.097 \times 10^{-3}$ ) unit for every one unit increase in haze. This shows that there is a marginal increment trend of the negative effect between haze and availability of company debt financing, which confirms $\mathrm{H}_{2}$.

Table 6. Result of the impact of $\mathrm{PM}_{2.5}$ on availability of company debt financing.

\begin{tabular}{|c|c|c|c|c|c|c|}
\hline \multirow{2}{*}{ LOAN_AVAIL $_{\text {it }} \times 1000$} & \multirow{2}{*}{ Fixed-Effects Model } & \multicolumn{5}{|c|}{ Quantile Regression Model } \\
\hline & & QR_10 & QR_30 & QR_50 & QR_70 & QR_90 \\
\hline PM2.5 it & $\begin{array}{l}-0.712 * * \\
(-2.469)\end{array}$ & $\begin{array}{c}-3.223 \\
(-1.373)\end{array}$ & $\begin{array}{l}-0.937 * * \\
(-1.996)\end{array}$ & $\begin{array}{c}-1.070 * * * \\
(-3.393)\end{array}$ & $\begin{array}{l}-1.207^{* *} \\
(-2.260)\end{array}$ & $\begin{array}{c}-3.097 \\
(-1.275)\end{array}$ \\
\hline $\mathrm{SIZE}_{\text {it }}$ & $\begin{array}{c}16.653^{* *} \\
(2.414)\end{array}$ & $\begin{array}{c}-1600.000 \\
* * * \\
(-6.307)\end{array}$ & $\begin{array}{c}-125.990 * * \\
(-2.532)\end{array}$ & $\begin{array}{c}119.673 * \\
(1.656)\end{array}$ & $\begin{array}{c}138.621 * * \\
(2.012)\end{array}$ & $\begin{array}{c}535.754^{* *} \\
(2.466)\end{array}$ \\
\hline $\mathrm{GROW}_{\mathrm{it}}$ & $\begin{array}{l}0.680 \\
(0.119)\end{array}$ & $\begin{array}{c}0.025 \\
(0.055)\end{array}$ & $\begin{array}{l}-0.023 \\
(-0.025)\end{array}$ & $\begin{array}{c}-0.034 \\
(-0.146)\end{array}$ & $\begin{array}{l}-0.043 \\
(-0.073)\end{array}$ & $\begin{array}{l}-0.087 \\
(-0.049)\end{array}$ \\
\hline $\mathrm{REV}_{\text {it }}$ & $\begin{array}{c}37.538^{* * *} \\
(5.430)\end{array}$ & $\begin{array}{c}1129.424^{* * *} \\
(4.709)\end{array}$ & $\begin{array}{l}70.911 \\
(1.480)\end{array}$ & $\begin{array}{l}-39.114 \\
(-1.397)\end{array}$ & $\begin{array}{l}-29.204 \\
(-0.659)\end{array}$ & $\begin{array}{l}-170.204 \\
(-1.216)\end{array}$ \\
\hline $\mathrm{ROA}_{\mathrm{it}}$ & $\begin{array}{l}16.318 \\
(0.810)\end{array}$ & $\begin{array}{c}82.543 * \\
(1.777)\end{array}$ & $\begin{array}{l}21.735 \\
(0.862)\end{array}$ & $\begin{array}{c}36.095 * \\
(1.776)\end{array}$ & $\begin{array}{l}15.571 \\
(0.989)\end{array}$ & $\begin{array}{l}-14.823 \\
(-0.580)\end{array}$ \\
\hline QUIC $_{\text {it }}$ & $\begin{array}{c}-6.857 \\
(-0.896)\end{array}$ & $\begin{array}{c}-54.067^{* *} \\
(-2.074)\end{array}$ & $\begin{array}{c}-19.906^{* * *} \\
(-2.577)\end{array}$ & $\begin{array}{l}-34.008 \\
(-1.496)\end{array}$ & $\begin{array}{l}-22.171 \\
(-1.189)\end{array}$ & $\begin{array}{l}17.754 \\
(1.178)\end{array}$ \\
\hline DEBT RATIO & $\begin{array}{c}305.447^{* * *} \\
(5.900)\end{array}$ & $\begin{array}{c}-510.000 * * * \\
(-7.740)\end{array}$ & $\begin{array}{l}-215.021 \\
(-1.006)\end{array}$ & $\begin{array}{c}615.793 \\
(1.638)\end{array}$ & $\begin{array}{c}1867.620 * * * \\
(4.807)\end{array}$ & $\begin{array}{c}6749.437^{* * *} \\
(11.153)\end{array}$ \\
\hline STATE $_{\text {it }}$ & $\begin{array}{l}-8.516 \\
(-0.141)\end{array}$ & $\begin{array}{c}-630.527^{* * *} \\
(-2.812)\end{array}$ & $\begin{array}{c}-204.204^{* * *} \\
(-5.365)\end{array}$ & $\begin{array}{c}-138.587^{* * *} \\
(-7.135)\end{array}$ & $\begin{array}{c}-102.870^{* * *} \\
(-3.241)\end{array}$ & $\begin{array}{l}63.417 \\
(0.516)\end{array}$ \\
\hline TOP10 ${ }_{\text {it }}$ & $\begin{array}{l}1.351 * * \\
(2.216)\end{array}$ & $\begin{array}{c}3.316 \\
(1.134) \\
\end{array}$ & $\begin{array}{c}-0.846 \\
(-0.929)\end{array}$ & $\begin{array}{c}-2.059 * * * \\
(-2.709)\end{array}$ & $\begin{array}{c}-2.283 * * * \\
(-3.037)\end{array}$ & $\begin{array}{c}1.223 \\
(0.516) \\
\end{array}$ \\
\hline $\mathrm{INDE}_{\text {it }}$ & $\begin{array}{c}-46.059 * * * \\
(-3.031)\end{array}$ & $\begin{array}{c}-337.072 * * * \\
(-3.212)\end{array}$ & $\begin{array}{c}-161.463 * * * \\
(-3.082)\end{array}$ & $\begin{array}{c}-57.030 * * * \\
(-2.961)\end{array}$ & $\begin{array}{c}-52.721^{* * *} \\
(-3.159)\end{array}$ & $\begin{array}{l}-63.554 \\
(-1.043)\end{array}$ \\
\hline DIR_CEO ${ }_{\text {it }}$ & $\begin{array}{l}11.364 \\
(0.681)\end{array}$ & $\begin{array}{l}-124.732 \\
(-1.595)\end{array}$ & $\begin{array}{l}-23.553 \\
(-1.100)\end{array}$ & $\begin{array}{c}-5.769 \\
(-0.340)\end{array}$ & $\begin{array}{c}4.989 \\
(0.183)\end{array}$ & $\begin{array}{l}-23.038 \\
(-0.402)\end{array}$ \\
\hline $\mathrm{EXCP}_{\text {it }}$ & $\begin{array}{l}-12.792 \\
(-1.571)\end{array}$ & $\begin{array}{c}305.471 \text { ** } \\
(2.041)\end{array}$ & $\begin{array}{c}250.760 * * * \\
(6.159)\end{array}$ & $\begin{array}{l}22.536 \\
(1.580)\end{array}$ & $\begin{array}{l}-28.603 \\
(-1.135)\end{array}$ & $\begin{array}{c}-546.824^{* * *} \\
(-3.309)\end{array}$ \\
\hline $\mathrm{MGT}_{\text {it }}$ & $\begin{array}{l}-48.385 \\
(-0.470)\end{array}$ & $\begin{array}{l}-215.819 \\
(-1.617)\end{array}$ & $\begin{array}{l}-45.365 \\
(-1.077)\end{array}$ & $\begin{array}{c}3.723 \\
(0.083) \\
\end{array}$ & $\begin{array}{l}33.117 \\
(0.430)\end{array}$ & $\begin{array}{l}-59.180 \\
(-0.259)\end{array}$ \\
\hline GDP_DIV $_{\text {it }}$ & $\begin{array}{c}(4.426) \\
-381.20^{9 * *} \\
\end{array}$ & $\begin{array}{c}(1.645) \\
3008.044 * *\end{array}$ & $\begin{array}{c}(1.691) \\
-517.240\end{array}$ & $\begin{array}{c}(0.583) \\
-464.063\end{array}$ & $\begin{array}{l}(-0.150) \\
-447.098\end{array}$ & $\begin{array}{c}(0.080) \\
-543.424\end{array}$ \\
\hline Constant & $\begin{array}{l}(-3.098) \\
-0.712 * *\end{array}$ & $\begin{array}{l}(2.163) \\
-3.223\end{array}$ & $\begin{array}{l}(-1.402) \\
-0.937 * *\end{array}$ & $\begin{array}{c}(-1.147) \\
-1.070 * * *\end{array}$ & $\begin{array}{l}(-0.886) \\
-1.207 * *\end{array}$ & $\begin{array}{c}(-0.290) \\
-3.097\end{array}$ \\
\hline $\mathrm{YEAR}_{\mathrm{it}}$ & control & & & control & & \\
\hline $\mathrm{INDU}_{\text {it }}$ & control & & & control & & \\
\hline $\operatorname{CITY}_{\text {it }}$ & control & & & control & & \\
\hline $\mathrm{N}$ & 7637 & & & 7637 & & \\
\hline $\operatorname{adj} . R^{2}$ & 0.178 & 0.312 & 0.268 & 0.256 & 0.250 & 0.234 \\
\hline $\mathrm{F}$ & 10.82 & - & - & - & - & - \\
\hline $\begin{array}{l}\text { Hausman test } \\
\text { (P Valve) }\end{array}$ & $\begin{array}{l}356.25 \\
(0.000)\end{array}$ & - & 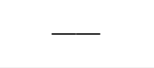 & - & - & - \\
\hline
\end{tabular}


In the control variables, the regression coefficient of SIZE $_{i t}$ is significantly positive, indicating that the larger the company size, the greater company debt financing availability. The regression coefficient of $\mathrm{REV}_{\text {it }}$ is significantly positive, which indicates total revenue increases the company debt financing availability. Among the governance variables, the regression coefficients of DEBT_RATIO $\mathrm{it}_{\text {it }}$ and INDE are significantly negative, indicating that the debt asset ratio and number of independent directors reduce the company debt financing availability. The regression coefficient of TOP10 $0_{\text {it }}$ is significantly positive, indicating that the higher the concentration of equity, the greater company debt financing availability. The other variables are not significant in the model, and it is difficult to judge the specific impact effect.

\subsection{The Moderating Role of Heavy Polluting Industries}

After controlling the impact of year $\left(\mathrm{YEAR}_{\mathrm{it}}\right)$, industry $\left(\mathrm{INDU}_{\mathrm{it}}\right)$ and region $\left(\mathrm{CITY}_{\mathrm{it}}\right)$, the paper uses fixed-effects model and adds interaction term of PM2.5 $5_{\text {it }}{ }^{*}$ POLLUTE it to estimate the model (4) and model (5) to test the characteristics of heavy polluting industries to haze and company debt. The moderating effect of the company debt financing relationship is shown in the Table 7 , the Chi-square statistics with degree of Hausman test are exceeded by the critical value at the $1 \%$ significance level $(P$ Value $=0.000)$. Therefore, we reject the null hypothesis and conclude that the fixed-effects model approach performs.

When talking about impact of haze on company debt financing demand, we can see that the coefficient of haze PM2. $5_{\text {it }}$ is significant positive at the $1 \%$ level, and the coefficient is 1.436 . After introducing the interaction of PM2. $5_{i t}{ }^{*}$ POLLUTE $_{i t}$, the coefficient of interaction is significantly negative at a $1 \%$ level, and the coefficient is -0.727 , indicating that the characteristics of heavy polluting industries have an inhibitory effect on the positive relationship between haze and the demand of company debt financing, that is, the characteristics of heavy polluting industries inhibit the positive impact of haze on the demand of company debt financing.

When talking about impact of haze on company debt financing availability, we can see that coefficient of haze PM2.5 $5_{\text {it }}$ is 0.112 , which is positive and significant at $1 \%$ level. After introducing the interaction of PM2.5 ${ }_{\text {it }}{ }^{*}$ POLLUTE $_{\text {it }}$, the coefficient of interaction is significant negative at the $5 \%$ level, and the coefficient is -0.024 , indicating that the characteristics of heavy pollution industries have an inhibitory impact on haze and company debt financing availability. In summary, $\mathrm{H}_{3}$ is supported by sample data.

In the control variables, the regression coefficient of $\mathrm{SIZE}_{\mathrm{it}}$ is significantly positive, indicating that the larger the company size, the greater company debt financing demand and availability in heavy polluting industries. The regression coefficient of $\mathrm{REV}_{\mathrm{it}}$ is significantly positive in model 1 and not significant in model 2 , which indicates that total revenue only increases the company debt financing demand in heavy polluting industries. The governance variables are not significant in the model, and it is difficult to judge the specific impact. 
Table 7. Result of moderating effects of heavy polluting industries.

\begin{tabular}{|c|c|c|}
\hline Fixed-Effects Model & IFTG_ASSET $_{\text {it }} \times 1000$ & LOAN_AVAI ${ }_{\text {Lit }} \times 1000$ \\
\hline PM2.5 $5_{\text {it }}$ & $\begin{array}{c}1.436^{* * *} \\
(5.248)\end{array}$ & $\begin{array}{c}0.112^{* * *} \\
(6.002)\end{array}$ \\
\hline PM2.5 $5_{\text {it }} \times$ POLLUTE $_{\text {it }}$ & $\begin{array}{l}-0.727^{* *} \\
(-2.397)\end{array}$ & $\begin{array}{c}-0.024^{* *} \\
(-1.183)\end{array}$ \\
\hline $\mathrm{SIZE}_{\mathrm{it}}$ & $\begin{array}{l}44.360^{* * * *} \\
(3.288)\end{array}$ & $\begin{array}{l}31.333^{* * *} \\
(34.194)\end{array}$ \\
\hline $\mathrm{GROW}_{\mathrm{it}}$ & $\begin{array}{l}-0.002 \\
(-0.955)\end{array}$ & $\begin{array}{l}-0.000 \\
(-0.118)\end{array}$ \\
\hline $\mathrm{REV}_{\text {it }}$ & $\begin{array}{c}-47.858^{* * *} \\
(-4.911)\end{array}$ & $\begin{array}{c}-0.882 \\
(-1.332)\end{array}$ \\
\hline $\mathrm{ROA}_{\mathrm{it}}$ & $\begin{array}{l}2.106 \\
(1.363)\end{array}$ & $\begin{array}{l}-0.039 \\
(-0.368)\end{array}$ \\
\hline $\mathrm{QUIC}_{\text {it }}$ & $\begin{array}{c}52.326^{* * * *} \\
(35.620)\end{array}$ & $\begin{array}{l}-2.768^{* * *} \\
(-27.739)\end{array}$ \\
\hline DEBT RATIO $_{\text {it }}$ & $\begin{array}{c}-57.831 * * * \\
(-25.341)\end{array}$ & $\begin{array}{c}0.699 * * * \\
(4.510)\end{array}$ \\
\hline STATE $_{\text {it }}$ & $\begin{array}{c}-39.830 * * \\
(-2.177)\end{array}$ & $\begin{array}{l}2.154^{*} \\
(1.733)\end{array}$ \\
\hline TOP10 $0_{\text {it }}$ & $\begin{array}{l}3.181^{* * *} \\
(13.112)\end{array}$ & $\begin{array}{c}-0.096^{* * *} \\
(-5.855)\end{array}$ \\
\hline $\mathrm{INDE}_{\mathrm{it}}$ & $\begin{array}{l}1.593 \\
(0.292)\end{array}$ & $\begin{array}{c}0.422 \\
(1.139)\end{array}$ \\
\hline DIR_CEO ${ }_{i t}$ & $\begin{array}{l}3.087 \\
(0.607)\end{array}$ & $\begin{array}{l}0.581 * \\
(1.683)\end{array}$ \\
\hline $\mathrm{EXCP}_{\text {it }}$ & $\begin{array}{c}9.893 \\
(1.220)\end{array}$ & $\begin{array}{c}-0.843 \\
(-1.530)\end{array}$ \\
\hline $\mathrm{MGT}_{\text {it }}$ & $\begin{array}{l}46.206 \\
(1.609)\end{array}$ & $\begin{array}{c}2.789 \\
(1.430)\end{array}$ \\
\hline GDP_DIV $_{\text {it }}$ & $\begin{array}{c}5.952 \\
(0.667)\end{array}$ & $\begin{array}{c}0.839 \\
(1.384)\end{array}$ \\
\hline Constant & $\begin{array}{c}-158.823 \\
(-1.441)\end{array}$ & $\begin{array}{c}-94.493^{* * *} \\
(-12.618)\end{array}$ \\
\hline $\mathrm{YEAR}_{\text {it }}$ & control & control \\
\hline $\mathrm{INDU}_{\mathrm{it}}$ & control & control \\
\hline CITY $_{\text {it }}$ & control & control \\
\hline $\mathrm{N}$ & 7637 & 7637 \\
\hline $\operatorname{adj} . R^{2}$ & 0.321 & 0.388 \\
\hline $\mathrm{F}$ & 182.143 & 244.248 \\
\hline $\begin{array}{l}\text { Hausman test } \\
\quad(P \text { Valve })\end{array}$ & $\begin{array}{l}362.22 \\
(0.001)\end{array}$ & $\begin{array}{l}317.33 \\
(0.000)\end{array}$ \\
\hline
\end{tabular}

Note: ${ }^{* * *}, * *$ and ${ }^{*}$ represent statistically significant at the $1 \%, 5 \%$ and $10 \%$ levels respectively; brackets are $t$ values.

\section{Robustness Test}

6.1. Use Air Quality Level $\left(A Q L_{i t}\right)$ Instead of PM2.5 to Test the Impact of Haze on Company Debt Financing

The comprehensive index of ambient air quality calculated and published by China Environmental Monitoring Station is as follows: 


$$
\begin{aligned}
\mathrm{AQL}_{\mathrm{it}} & =\text { air quality level } \\
& =\sum\left(\frac{\mathrm{SO}_{2} \text { Monitoring value (average) }}{\mathrm{SO}_{2} \text { Secondary standard value }}\right. \\
& +\frac{\mathrm{NO}_{2} \text { Monitoring value (average) }}{\mathrm{NO}_{2} \text { Secondary standard value }} \\
& +\frac{\left.\mathrm{PM}_{10} \text { Monitoring value (average }\right)}{\mathrm{PM}_{10} \text { Secondary standard value }} \\
& +\frac{\mathrm{CO} \text { Monitoring value (average) }}{\mathrm{CO} \text { Secondary standard value }} \\
& +\frac{\mathrm{O} 38 \mathrm{~h} \text { Monitoring value (average })}{\mathrm{O}_{38 h} \text { Secondary standard value }} \\
& \left.+\frac{\mathrm{PM}_{2.5} \text { Monitoring value (average) }}{\mathrm{PM}_{2.5} \text { Secondary standard value }}\right)
\end{aligned}
$$

\begin{tabular}{|c|c|c|c|c|c|c|}
\hline \multirow{2}{*}{ IFTG_ASSET $_{\text {it }} \times 1000$} & \multirow{2}{*}{ Fixed-Effects Model } & \multicolumn{5}{|c|}{ Quantile Regression Model } \\
\hline & & QR_10 & QR_25 & QR_50 & QR_75 & QR_90 \\
\hline $\mathrm{AQL}_{\text {it }}$ & $\begin{array}{c}8.017^{* * *} \\
(4.416)\end{array}$ & $\begin{array}{c}5.867 \\
(1.383) \\
\end{array}$ & $\begin{array}{l}6.712 * * \\
(2.111)\end{array}$ & $\begin{array}{l}7.981^{* * *} \\
(3.828)\end{array}$ & $\begin{array}{c}9.315^{* * *} \\
(3.748)\end{array}$ & $\begin{array}{c}10.132 * * * \\
(3.016)\end{array}$ \\
\hline $\mathrm{SIZE}_{\mathrm{it}}$ & $\begin{array}{c}12.611^{* * *} \\
(5.723)\end{array}$ & $\begin{array}{l}27.026 \\
(1.514) \\
\end{array}$ & $\begin{array}{l}21.362 \\
(1.597)\end{array}$ & $\begin{array}{l}12.858 \\
(1.464)\end{array}$ & $\begin{array}{c}3.914 \\
(0.374) \\
\end{array}$ & $\begin{array}{l}-1.560 \\
(-0.110)\end{array}$ \\
\hline $\mathrm{GROW}_{\mathrm{it}}$ & $\begin{array}{c}2.333 \\
(1.273)\end{array}$ & $\begin{array}{c}3.833 \\
(0.699)\end{array}$ & $\begin{array}{c}3.244 \\
(0.789)\end{array}$ & $\begin{array}{l}2.358 \\
(0.875)\end{array}$ & $\begin{array}{l}1.427 \\
(0.444)\end{array}$ & $\begin{array}{c}0.858 \\
(0.197)\end{array}$ \\
\hline $\mathrm{REV}_{\text {it }}$ & $\begin{array}{c}0.550 \\
(0.249)\end{array}$ & $\begin{array}{c}1.738 \\
(0.129)\end{array}$ & $\begin{array}{c}1.271 \\
(0.126)\end{array}$ & $\begin{array}{c}0.570 \\
(0.086)\end{array}$ & $\begin{array}{c}-0.167 \\
(-0.021)\end{array}$ & $\begin{array}{c}-0.618 \\
(-0.058)\end{array}$ \\
\hline $\mathrm{ROA}_{\mathrm{it}}$ & $\begin{array}{c}21.169 * * * \\
(3.290)\end{array}$ & $\begin{array}{c}1.945 \\
(0.095)\end{array}$ & $\begin{array}{c}9.499 \\
(0.616)\end{array}$ & $\begin{array}{c}20.840^{* *} \\
(2.059)\end{array}$ & $\begin{array}{c}32.767^{* * *} \\
(2.719)\end{array}$ & $\begin{array}{c}40.068^{* *} \\
(2.459)\end{array}$ \\
\hline $\mathrm{QUIC}_{\text {it }}$ & $\begin{array}{c}75.243^{* * *} \\
(30.758)\end{array}$ & $\begin{array}{c}85.517^{* * *} \\
(6.055)\end{array}$ & $\begin{array}{c}81.480 * * * \\
(7.699)\end{array}$ & $\begin{array}{c}75.419^{* * *} \\
(10.854)\end{array}$ & $\begin{array}{c}69.045^{* * *} \\
(8.344)\end{array}$ & $\begin{array}{c}65.143^{* * *} \\
(5.824)\end{array}$ \\
\hline DEBT RATIO $_{\text {it }}$ & $\begin{array}{c}-205.176^{* * *} \\
(-12.402)\end{array}$ & $\begin{array}{l}-72.774 \\
(-0.665) \\
\end{array}$ & $\begin{array}{l}-124.800 \\
(-1.521) \\
\end{array}$ & $\begin{array}{c}-202.906 \text { *** } \\
(-3.760)\end{array}$ & $\begin{array}{c}-285.056 \text { *** } \\
(-4.442)\end{array}$ & $\begin{array}{c}-335.338 \text { *** } \\
(-3.867)\end{array}$ \\
\hline STATE $_{\text {it }}$ & $\begin{array}{c}-36.060 * \\
(-1.868)\end{array}$ & $\begin{array}{l}-59.692 \\
(-0.894) \\
\end{array}$ & $\begin{array}{l}-50.406 \\
(-1.008) \\
\end{array}$ & $\begin{array}{l}-36.465 \\
(-1.112) \\
\end{array}$ & $\begin{array}{l}-21.803 \\
(-0.558) \\
\end{array}$ & $\begin{array}{l}-12.828 \\
(-0.243) \\
\end{array}$ \\
\hline TOP10 ${ }_{\text {it }}$ & $\begin{array}{c}1.603^{* * *} \\
(8.230)\end{array}$ & $\begin{array}{l}1.464 * \\
(1.801)\end{array}$ & $\begin{array}{l}1.519 * * \\
(2.493)\end{array}$ & $\begin{array}{c}1.601^{* * *} \\
(4.007)\end{array}$ & $\begin{array}{c}1.687^{* * *} \\
(3.542)\end{array}$ & $\begin{array}{c}1.740 * * * \\
(2.702)\end{array}$ \\
\hline $\mathrm{INDE}_{\text {it }}$ & $\begin{array}{c}10.842 * * \\
(2.232)\end{array}$ & $\begin{array}{c}3.912 \\
(0.267) \\
\end{array}$ & $\begin{array}{l}6.635 \\
(0.604) \\
\end{array}$ & $\begin{array}{l}10.723 \\
(1.490)\end{array}$ & $\begin{array}{c}15.023 * \\
(1.751)\end{array}$ & $\begin{array}{l}17.655 \\
(1.522)\end{array}$ \\
\hline DIR_CEO ${ }_{\text {it }}$ & $\begin{array}{c}2.504 \\
(0.470) \\
\end{array}$ & $\begin{array}{c}2.004 \\
(0.103) \\
\end{array}$ & $\begin{array}{c}2.200 \\
(0.151) \\
\end{array}$ & $\begin{array}{c}2.495 \\
(0.261) \\
\end{array}$ & $\begin{array}{c}2.805 \\
(0.246) \\
\end{array}$ & $\begin{array}{c}2.995 \\
(0.194) \\
\end{array}$ \\
\hline $\mathrm{EXCP}_{\text {it }}$ & $\begin{array}{c}-0.651 \\
(-0.250) \\
\end{array}$ & $\begin{array}{l}-4.667 \\
(-0.376) \\
\end{array}$ & $\begin{array}{c}-3.089 \\
(-0.332) \\
\end{array}$ & $\begin{array}{c}-0.720 \\
(-0.118) \\
\end{array}$ & $\begin{array}{c}1.773 \\
(0.244) \\
\end{array}$ & $\begin{array}{c}3.298 \\
(0.335) \\
\end{array}$ \\
\hline $\mathrm{MGT}_{\text {it }}$ & $\begin{array}{l}41.924 \\
(1.273)\end{array}$ & $\begin{array}{l}37.352 \\
(0.432)\end{array}$ & $\begin{array}{l}39.149 \\
(0.605)\end{array}$ & $\begin{array}{l}41.846 \\
(0.986)\end{array}$ & $\begin{array}{l}44.682 \\
(0.883)\end{array}$ & $\begin{array}{l}46.419 \\
(0.679)\end{array}$ \\
\hline GDP_DIV $_{\text {it }}$ & $\begin{array}{l}-6.660 * * \\
(-2.304)\end{array}$ & $\begin{array}{c}-9.594 \\
(-1.510) \\
\end{array}$ & $\begin{array}{l}-8.441 * \\
(-1.773)\end{array}$ & $\begin{array}{c}-6.710 * * \\
(-2.149)\end{array}$ & $\begin{array}{c}-4.890 \\
(-1.314) \\
\end{array}$ & $\begin{array}{c}-3.775 \\
(-0.751) \\
\end{array}$ \\
\hline Constant & $\begin{array}{l}-51.470 \\
(-1.286)\end{array}$ & $\begin{array}{l}-11.25 \\
(-0.70)\end{array}$ & $\begin{array}{l}-5.604 \\
(-0.19)\end{array}$ & $\begin{array}{l}1.294 \\
(1.27)\end{array}$ & $\begin{array}{l}0.718 \\
(0.92)\end{array}$ & $\begin{array}{l}-0.0887 \\
(-0.06)\end{array}$ \\
\hline $\mathrm{YEAR}_{\mathrm{it}}$ & control & & & control & & \\
\hline $\mathrm{INDU}_{\text {it }}$ & control & & & control & & \\
\hline $\mathrm{CITY}_{\text {it }}$ & control & & & control & & \\
\hline $\mathrm{N}$ & 7637 & & & 7637 & & \\
\hline $\operatorname{adj} . R^{2}$ & 0.102 & 0.077 & 0.027 & 0.057 & 0.115 & 0.213 \\
\hline $\mathrm{F}$ & 194.583 & - & - & - & - & - \\
\hline
\end{tabular}

In the paper, $\mathrm{PM}_{2.5}$ is replaced by the monitoring data of air quality level $\left(\mathrm{AQL}_{\mathrm{it}}\right)$ issued by China Environmental Monitoring Station as an dependent variable to test the impact of haze. The O38h is ozone, in the ambient air quality standard (GB3095-2012), O38h is a major pollutant and the standard limits are given. From fixed-effects model of Table 8, we can see that the coefficient of AQL it is 8.017 and it is positive and significant at the level of $5 \%$, which shows that haze has a positive impact on the demand of company debt financing, the results are consistent with the result of Table 5 .

Table 8. Result of the impact of AQL on the demand of company debt financing. 
Quantile regression model is used to estimate the marginal effect of haze on company debt financing availability. The results are shown in Quantile Regression of Table 8. The model controls the impact of year $\left(\mathrm{YEAR}_{\mathrm{it}}\right)$, industry $\left(\mathrm{CITY}_{\mathrm{it}}\right)$, and region $\left(\mathrm{INDU}_{\mathrm{it}}\right)$. In the panel quantile model, five representative loci are selected: $10 \%, 25 \%, 50 \%, 75 \%$, and $90 \%$.

In quantile regression of Table 8 , the regression coefficients of $A Q L_{i t}$ are all significant positive at the quantile range of $25 \%, 50 \%, 75 \%$, and $90 \%$ level, which indicates that haze has a positive impact on the demand of company debt financing. Comparing the regression coefficients of $A Q L_{i t}$ of different quantiles, which are rising steadily from 5.867 to 10.132 . This shows that there is a marginal increment trend of the positive effect between haze and demand of company debt financing, which confirms $\mathrm{H}_{1}$.

From fixed-effects model of Table 9, we can see that the coefficient of $A Q L_{i t}$ is significantly negative at the level of $5 \%$, and the coefficient is -1.931 , which shows that haze has a negative impact on the availability of company debt financing, the results are consistent with Table 7.

Table 9. Result of the impact of AQL on availability of company debt financing.

\begin{tabular}{|c|c|c|c|c|c|c|}
\hline \multirow{2}{*}{ LOAN_AVAIL ${ }_{\text {it }} \times 1000$} & \multirow{2}{*}{ Fixed-Effects Model } & \multicolumn{5}{|c|}{ Quantile Regression Model } \\
\hline & & QR_10 & QR_25 & QR_50 & QR_75 & QR_90 \\
\hline $\mathrm{AQL}_{\mathrm{it}}$ & $\begin{array}{c}-1.931 * * * \\
(-3.40)\end{array}$ & $\begin{array}{c}-0.671 \\
(-0.863)\end{array}$ & $\begin{array}{l}-1.203 \\
(-1.517)\end{array}$ & $\begin{array}{l}-1.887 * * * \\
(-3.279)\end{array}$ & $\begin{array}{l}-2.467^{* * *} \\
(-4.267)\end{array}$ & $\begin{array}{l}-2.450 * * \\
(-2.196)\end{array}$ \\
\hline $\mathrm{SIZE}_{\text {it }}$ & $\begin{array}{c}1.666^{* *} \\
(2.42)\end{array}$ & $\begin{array}{c}7.375^{* * *} \\
(7.900)\end{array}$ & $\begin{array}{c}16.131^{* * *} \\
(16.373)\end{array}$ & $\begin{array}{c}15.730^{* * *} \\
(4.258)\end{array}$ & $\begin{array}{l}8.914^{* *} \\
(2.097)\end{array}$ & $\begin{array}{l}4.498^{* *} \\
(2.197)\end{array}$ \\
\hline $\mathrm{GROW}_{\mathrm{it}}$ & $\begin{array}{l}0.066 \\
(0.12)\end{array}$ & $\begin{array}{l}-1.207 \\
(-1.523)\end{array}$ & $\begin{array}{l}-1.315 \\
(-1.135)\end{array}$ & $\begin{array}{l}-3.466^{* * *} \\
(-4.258)\end{array}$ & $\begin{array}{c}-5.280 * * * \\
(-4.676)\end{array}$ & $\begin{array}{l}-4.401 * * \\
(-2.112)\end{array}$ \\
\hline $\mathrm{REV}_{\mathrm{it}}$ & $\begin{array}{c}3.761^{* * *} \\
(5.44)\end{array}$ & $\begin{array}{c}-0.566 \\
(-0.556)\end{array}$ & $\begin{array}{l}-3.019 * * \\
(-2.370)\end{array}$ & $\begin{array}{c}-4.608 \\
(-1.347)\end{array}$ & $\begin{array}{l}-10.517 * \\
(-1.915)\end{array}$ & $\begin{array}{c}-18.124^{* * *} \\
(-3.540)\end{array}$ \\
\hline $\mathrm{ROA}_{\mathrm{it}}$ & $\begin{array}{l}1.556 \\
(0.77)\end{array}$ & $\begin{array}{c}2.901 \\
(1.533)\end{array}$ & $\begin{array}{l}-4.664 \\
(-1.404)\end{array}$ & $\begin{array}{c}-10.339^{* * *} \\
(-2.852)\end{array}$ & $\begin{array}{l}-12.196^{* *} \\
(-2.222)\end{array}$ & $\begin{array}{c}-22.575^{* * *} \\
(-3.307)\end{array}$ \\
\hline QUIC $_{\text {it }}$ & $\begin{array}{l}-0.747 \\
(-0.98)\end{array}$ & $\begin{array}{c}-7.499 * * * \\
(-7.670)\end{array}$ & $\begin{array}{c}-9.510^{* * *} \\
(-8.105)\end{array}$ & $\begin{array}{c}-10.117^{* * *} \\
(-8.470)\end{array}$ & $\begin{array}{c}-9.037^{* * *} \\
(-8.491)\end{array}$ & $\begin{array}{l}-9.865^{* * *} \\
(-4.245)\end{array}$ \\
\hline DEBT RATIO $_{\text {it }}$ & $\begin{array}{c}30.130 \text { ** } \\
(5.82)\end{array}$ & $\begin{array}{c}111.890^{* * *} \\
(16.238)\end{array}$ & $\begin{array}{c}263.369^{* * *} \\
(25.667)\end{array}$ & $\begin{array}{c}411.625^{* * *} \\
(50.779)\end{array}$ & $\begin{array}{c}539.378^{* * *} \\
(38.620)\end{array}$ & $\begin{array}{c}612.912 * * * \\
(30.204)\end{array}$ \\
\hline STATE $_{\text {it }}$ & $\begin{array}{l}-0.815 \\
(-0.14)\end{array}$ & $\begin{array}{c}-13.337^{* * *} \\
(-4.612)\end{array}$ & $\begin{array}{c}-18.594 * * * \\
(-6.609)\end{array}$ & $\begin{array}{c}-12.490 * * * \\
(-3.512)\end{array}$ & $\begin{array}{l}5.566^{*} \\
(1.803)\end{array}$ & $\begin{array}{c}15.846 * * \\
(2.474)\end{array}$ \\
\hline TOP10 ${ }_{\text {it }}$ & $\begin{array}{c}0.136^{* *} \\
(2.23)\end{array}$ & $\begin{array}{l}-0.277^{* * *} \\
(-3.687)\end{array}$ & $\begin{array}{l}-0.364^{* * *} \\
(-3.720)\end{array}$ & $\begin{array}{l}-0.244^{* * *} \\
(-2.612)\end{array}$ & $\begin{array}{l}-0.249^{*} \\
(-1.919)\end{array}$ & $\begin{array}{c}0.109 \\
(0.597)\end{array}$ \\
\hline $\mathrm{INDE}_{\mathrm{it}}$ & $\begin{array}{l}-4.549 \text { ** } \\
-2.99\end{array}$ & $\begin{array}{c}-5.348^{* * *} \\
(-3.177)\end{array}$ & $\begin{array}{c}-3.152 \\
(-1.193)\end{array}$ & $\begin{array}{c}-3.630 \\
(-1.089)\end{array}$ & $\begin{array}{c}0.278 \\
(0.101) \\
\end{array}$ & $\begin{array}{c}2.859 \\
(0.876) \\
\end{array}$ \\
\hline DIR_CEO ${ }_{\text {it }}$ & $\begin{array}{l}1.215 \\
(0.73)\end{array}$ & $\begin{array}{c}2.291 \\
(1.589)\end{array}$ & $\begin{array}{c}2.666 \\
(0.972) \\
\end{array}$ & $\begin{array}{c}3.091 \\
(0.854) \\
\end{array}$ & $\begin{array}{c}0.972 \\
(0.258) \\
\end{array}$ & $\begin{array}{l}-9.649 * \\
(-1.941)\end{array}$ \\
\hline $\mathrm{EXCP}_{\text {it }}$ & $\begin{array}{l}-1.231 \\
(-1.51)\end{array}$ & $\begin{array}{c}0.609 \\
(0.311) \\
\end{array}$ & $\begin{array}{c}-1.902 \\
(-0.679)\end{array}$ & $\begin{array}{c}1.284 \\
(1.611) \\
\end{array}$ & $\begin{array}{c}3.053 \\
(1.603) \\
\end{array}$ & $\begin{array}{c}-2.458 \\
(-0.730)\end{array}$ \\
\hline $\mathrm{MGT}_{\mathrm{it}}$ & $\begin{array}{l}-4.317 \\
(-0.42) \\
\end{array}$ & $\begin{array}{c}16.895^{* * * *} \\
(2.633)\end{array}$ & $\begin{array}{c}21.794 * \\
(1.694)\end{array}$ & $\begin{array}{l}16.083 \\
(1.429) \\
\end{array}$ & $\begin{array}{c}6.620 \\
(0.504) \\
\end{array}$ & $\begin{array}{l}-27.034 \\
(-1.447)\end{array}$ \\
\hline GDP_DIV $_{\text {it }}$ & $\begin{array}{c}3.944 * * \\
(4.36)\end{array}$ & $\begin{array}{c}0.860 \\
(0.759)\end{array}$ & $\begin{array}{c}-1.584 \\
(-0.957)\end{array}$ & $\begin{array}{c}-1.351 \\
(-0.768)\end{array}$ & $\begin{array}{l}3.025^{* *} \\
(2.118)\end{array}$ & $\begin{array}{l}3.897^{*} \\
(1.775)\end{array}$ \\
\hline Constant & $\begin{array}{c}-32.650 * * \\
(-2.61)\end{array}$ & $\begin{array}{c}-39.957^{* * *} \\
(-2.594)\end{array}$ & $\begin{array}{c}-77.337 * * * \\
(-3.207)\end{array}$ & $\begin{array}{c}-75.557 * * * \\
(-3.9997)\end{array}$ & $\begin{array}{l}15.901 \\
(0.396) \\
\end{array}$ & $\begin{array}{c}167.450 * * * \\
(3.594)\end{array}$ \\
\hline $\mathrm{YEAR}_{\mathrm{it}}$ & control & & & control & & \\
\hline $\mathrm{INDU}_{\text {it }}$ & control & & & control & & \\
\hline $\mathrm{CITY}_{\text {it }}$ & control & & & control & & \\
\hline $\mathrm{N}$ & 7637 & & & 7637 & & \\
\hline $\operatorname{adj} . R^{2}$ & 0.0759 & 0.074 & 0.1666 & 0.2674 & 0.3119 & 0.3044 \\
\hline $\mathrm{F}$ & 11.22 & - & - & - & - & - \\
\hline
\end{tabular}

Note: ${ }^{* *},{ }^{* *}$ and ${ }^{*}$ represent statistically significant at the $1 \%, 5 \%$ and $10 \%$ levels respectively; brackets are $t$ values.

In quantile regression of Table 9, the regression coefficients of $A Q L_{i t}$ are significantly negative at the quantile range of $50 \%, 75 \%$, and $90 \%$ level, which indicates that haze has a negative impact on the availability of company debt financing. Comparing the regression coefficients of $A Q L_{i t}$ of different 
quantiles, which are decreasing steadily from -0.671 to -2.450 , which shows that there is a marginal increment trend of the negative effect between haze and availability of company debt financing and confirms the $\mathrm{H}_{2}$.

From Table 10, we can see that when talking about impact of haze on company debt financing demand, coefficient of $A Q L_{i t}$ is significantly positive at the $1 \%$ level, and the coefficient is 20.132 . The coefficient of $A Q L_{i t}{ }^{*} P$ OLLUTE $E_{i t}$ is significantly negative at $5 \%$ level, and the coefficient is -6.461 . This indicates that the characteristics of heavy polluting industries have a negative impact on the relationship of haze and the company debt financing demand. That is to say, the characteristics of heavy polluting industries inhibit the positive impact of the demand of company debt financing, the results are consistent with Table 7.

Table 10. Result of moderating effects of heavy polluting industries.

\begin{tabular}{|c|c|c|}
\hline Fixed-Effects Model & IFTG_ASSET $_{\text {it }} \times 1000$ & LOAN_AVAILit $\times 1000$ \\
\hline $\mathrm{AQL}_{\text {it }}$ & $\begin{array}{c}20.132 * * * \\
(4.436)\end{array}$ & $\begin{array}{c}21.197^{* * *} \\
(6.886)\end{array}$ \\
\hline $\mathrm{AQL}_{\mathrm{it}} \times \mathrm{POLLUTE}_{\mathrm{it}}$ & $\begin{array}{l}-6.461^{* *} \\
(-1.232)\end{array}$ & $\begin{array}{l}-7.636^{* *} \\
(-2.147)\end{array}$ \\
\hline SIZE $_{i t}$ & $\begin{array}{c}45.396^{* * *} \\
(3.382)\end{array}$ & $\begin{array}{c}316.255^{* * * *} \\
(34.734)\end{array}$ \\
\hline $\mathrm{GROW}_{\mathrm{it}}$ & $\begin{array}{l}-0.002 \\
(-0.922)\end{array}$ & $\begin{array}{l}-0.000 \\
(-0.098)\end{array}$ \\
\hline $\mathrm{REV}_{\text {it }}$ & $\begin{array}{c}-48.653^{* * *} \\
(-4.991)\end{array}$ & $\begin{array}{l}-9.978 \\
(-1.509)\end{array}$ \\
\hline $\mathrm{ROA}_{\mathrm{it}}$ & $\begin{array}{l}2.182 \\
(1.413)\end{array}$ & $\begin{array}{l}-0.360 \\
(-0.344)\end{array}$ \\
\hline $\mathrm{QUIC}_{\mathrm{it}}$ & $\begin{array}{c}52.279 * * * \\
(35.599)\end{array}$ & $\begin{array}{l}-27.694^{* * *} \\
(-27.803)\end{array}$ \\
\hline DEBT RATIO $_{i t}$ & $\begin{array}{l}-57.836^{* * *} \\
(-25.348)\end{array}$ & $\begin{array}{c}7.032^{* * *} \\
(4.544)\end{array}$ \\
\hline STATE $_{i t}$ & $\begin{array}{l}-40.732 * * \\
(-2.226)\end{array}$ & $\begin{array}{l}20.738^{*} \\
(1.671)\end{array}$ \\
\hline $\mathrm{TOP}_{10}$ & $\begin{array}{l}3.154^{* * *} \\
(13.025)\end{array}$ & $\begin{array}{c}-0.972^{* * *} \\
(-5.919)\end{array}$ \\
\hline $\mathrm{INDE}_{\mathrm{it}}$ & $\begin{array}{c}1.578 \\
(0.289)\end{array}$ & $\begin{array}{c}4.123 \\
(1.114)\end{array}$ \\
\hline DIR_CEO ${ }_{i t}$ & $\begin{array}{c}3.031 \\
(0.596)\end{array}$ & $\begin{array}{l}5.613 \\
(1.627)\end{array}$ \\
\hline $\mathrm{EXCP}_{\mathrm{it}}$ & $\begin{array}{c}9.950 \\
(1.227)\end{array}$ & $\begin{array}{l}-8.539 \\
(-1.553)\end{array}$ \\
\hline $\mathrm{MGT}_{\mathrm{it}}$ & $\begin{array}{l}47.276^{*} \\
(1.647)\end{array}$ & $\begin{array}{l}28.951 \\
(1.487)\end{array}$ \\
\hline GDP_DIV $_{\text {it }}$ & $\begin{array}{l}-12.660 \\
(-1.513)\end{array}$ & $\begin{array}{l}-9.944 * \\
(-1.752)\end{array}$ \\
\hline Constant & $\begin{array}{l}-82.267 \\
(-0.819)\end{array}$ & $\begin{array}{c}-887.009^{* * *} \\
(-13.022)\end{array}$ \\
\hline $\mathrm{YEAR}_{\mathrm{it}}$ & control & control \\
\hline $\mathrm{INDU}_{\text {it }}$ & control & control \\
\hline CITY $_{\text {it }}$ & control & control \\
\hline $\mathrm{N}$ & 7637 & 7637 \\
\hline adj. $R^{2}$ & 0.103 & 0.194 \\
\hline $\mathrm{F}$ & 182.376 & 246.382 \\
\hline
\end{tabular}

Note: ${ }^{* * *}, * *$ and $*$ represent statistically significant at the $1 \%, 5 \%$, and $10 \%$ levels, respectively; brackets are $t$ values. 
When talking about impact of haze on company debt financing availability, we can see that the coefficient of $A Q L_{i t}$ is significantly positive at $1 \%$ level, the coefficient of $A Q L_{i t}{ }^{*} \mathrm{POLLUTE}_{i t}$ is significantly negative at $5 \%$ level, and the coefficient is -7.636 . This indicates that the characteristics of heavy polluting industries have an inhibitory impact on the relationship of haze and the company debt financing availability. That is, the characteristics of heavy polluting industries inhibit the impact on availability of company debt financing, and the results are consistent with of Table 7 .

\subsection{Propensity Score Matching}

According to the Environmental Kuznets curve, there is an inverted-U-shaped relationship between environmental pollution and income, the environmental pollution increases up to a certain level as income goes up, then decrease. It can be seen, there is a certain endogenous nature between air pollution and the operating conditions of companies from the macroeconomic point of view. Therefore, in order to further eliminate the endogenous problem between air pollution and the availability of company debt financing, we use the propensity score matching method (PSM) in this paper learning from the research of Lim et al. [61]. As the World Health Organization (WHO) believes that a PM2.5 of less than 10 is a safe value. For developing countries, WHO has developed guidelines for three different stages. According to the provisions of the WHO and the actual situation in China, we define PM2.5 greater than 50 as pollution in the paper. In this method, the groups that $\mathrm{PM}_{2.5}$ is less than $50\left(\mathrm{IF}_{-} \mathrm{HAZE}_{\mathrm{it}}=0\right)$ are as control group and those that $\mathrm{PM}_{2.5}$ is greater than $50\left(\mathrm{IF}_{-} \mathrm{HAZE}_{\mathrm{it}}=1\right)$ are as treatment groups, which are used to test whether there were significant differences between the companies without regional haze pollution and those with regional haze pollution. The characteristics of the matching control group are designed to mitigate (but not eliminate) interference with non-random selection. In the process of matching, logistic regression is used to calculate the tendency value, we choose radius matching, and then the balance after matching is evaluated to calculate the average intervention impact.

Table 11 shows that the statistical characteristics of control group and treatment group variables are not significant after matching. This test further confirms the effectiveness of the matching strategy in the paper. Table 12 reports results based on PSM samples. The table shows that the normalized deviation (\% bias) of most variables after being matched is less than 10, while most $t$-tests do not reject the assumption that there is no systematic difference between the treatment group and the control group. The standard deviation of most variables has been greatly reduced. This model further proves that our empirical results are robust. 
Table 11. Covariate balance diagnosis.

\begin{tabular}{|c|c|c|c|c|c|c|c|c|}
\hline \multirow{2}{*}{ Variable } & \multirow{2}{*}{ Unmatched Matched } & \multicolumn{2}{|c|}{ Mean } & \multirow{2}{*}{$\%$ Bias } & \multirow{2}{*}{$\%$ Reduct Bias } & \multicolumn{2}{|c|}{ t-Test } & \multirow{2}{*}{$\mathrm{V}(\mathrm{T}) / \mathrm{V}(\mathrm{C})$} \\
\hline & & Treated & Control & & & $t$ & $p>t$ & \\
\hline $\mathrm{SIZE}_{\text {it }}$ & Unmatched & 9.509 & 9.553 & -3.0 & & -1.30 & 0.194 & $1.22 *$ \\
\hline \multirow{2}{*}{$\mathrm{GROW}_{\text {it }}$} & Unmatched & 0.458 & 0.453 & 0.5 & & 0.22 & 0.825 & $1.02 * * *$ \\
\hline & Matched & 0.457 & 0.480 & -2.2 & -337.8 & -0.99 & 0.321 & $0.81 *$ \\
\hline \multirow{2}{*}{$\mathrm{ROA}_{\mathrm{it}}$} & Unmatched & 0.166 & 0.193 & -9.3 & & -4.08 & 0.000 & $0.93^{* * *}$ \\
\hline & Matched & 0.166 & 1.673 & -0.2 & 97.8 & -0.10 & 0.917 & $1.25^{* * *}$ \\
\hline \multirow{2}{*}{ QUIC $_{\text {it }}$} & Unmatched & 1.341 & 1.399 & -5.2 & & -2.27 & 0.023 & 0.97 \\
\hline & Matched & 1.343 & 1.364 & -1.9 & 63.7 & -0.88 & 0.381 & $0.90 *$ \\
\hline DEBT & Unmatched & 0.465 & 0.454 & 5.4 & & 2.33 & 0.020 & $1.08 *$ \\
\hline \multirow{2}{*}{$\mathrm{INDE}_{\text {it }}$} & Unmatched & 3.200 & 3.152 & 7.8 & & 3.39 & 0.001 & 1.04 \\
\hline & Matched & 3.198 & 3.215 & -2.8 & 64.5 & -1.27 & 0.205 & $0.90^{*}$ \\
\hline \multirow{2}{*}{ DIR_CEO ${ }_{\text {it }}$} & Unmatched & 1.757 & 1.698 & 12.6 & & 5.51 & 0.000 & $0.85 *$ \\
\hline & Matched & 1.757 & 1.739 & 3.9 & 69.0 & 1.91 & 0.056 & 0.99 \\
\hline \multirow{2}{*}{$\mathrm{EXCP}_{\text {it }}$} & Unmatched & 6.113 & 6.137 & -2.6 & & -1.15 & 0.249 & $0.82 *$ \\
\hline & Matched & 6.116 & 6.135 & -2.1 & 20.2 & -1.02 & 0.310 & $0.86^{*}$ \\
\hline \multirow{2}{*}{$\mathrm{MGT}_{\text {it }}$} & Unmatched & 0.050 & 0.056 & -5.1 & & -2.24 & 0.025 & 0.97 \\
\hline & Matched & 0.050 & 0.054 & -3.1 & 38.9 & -1.47 & 0.142 & $0.95^{* * *}$ \\
\hline \multirow{2}{*}{ GDP_DIV it } & Unmatched & 5.469 & 5.567 & -13.6 & & -5.85 & 0.000 & $1.44 *$ \\
\hline & Matched & 5.469 & 5.482 & -1.9 & 85.9 & -0.85 & 0.393 & $1.12 *$ \\
\hline
\end{tabular}

Table 12. PSM results of the effect of haze on company debt financing.

\begin{tabular}{cccc}
\hline Outcome variable $=$ IFTG_ASSET $_{\text {it }}$ & Mean & Difference & t-Statistics \\
\hline IF_HAZE $_{\text {it }}=1$ & 0.093 & 0.014 & $2.100^{* *}$ \\
IF_HAZE $_{\text {it }}=0$ & 0.079 & & \\
\hline Outcome variable $=$ LOAN_AVAIL $_{\text {it }}$ & Mean & Difference & t-Statistics \\
\hline IF_HAZE $_{i t}=1$ & 1.886 & 0.246 & $3.040^{* * *}$ \\
IF_HAZE $_{\text {it }}=0$ & 2.132 & &
\end{tabular}

Note: ${ }^{* * *}, * *$ and ${ }^{*}$ represent statistically significant at the $1 \%, 5 \%$ and $10 \%$ levels respectively; brackets are $t$ values.

\section{Conclusions}

This paper takes the annual reports of A-share listed companies in Shanghai and Shenzhen Stock Exchanges from 2007 to 2016 as a sample to test the relationship between haze and company debt financing availability and founds that: First, haze has a positive impact on the demand of company debt financing, and the positive effect is marginal increment. This shows that the haze pollution increases excessive cash outflows and increases the capital demand of companies in China. Second, haze has a negative impact on the availability of company debt financing, and the negative impact is marginal increment, which shows that under the haze pollution, the companies take on large amount of environmental compensation costs, capital costs, environmental liability liabilities, and high operational risks, thus companies face a higher level of credit constraints. Third, the characteristics of heavy polluting industries have weakened the impact of haze on company debt financing. During the haze generation period, heavy polluting companies take on more environmental costs, which results in cash outflow of companies, so that the bank's credit evaluation of heavy polluting companies will be reduced, and the debt financing of heavy polluting companies will be reduced.

Environmental problems have become increasingly serious in China, especially the problem of haze pollution. This paper analyzes the influence of air pollution on enterprise management from the perspective of companies debt financing and proved the availability of company debt finance 
has been accelerating and declining in the face of haze pollution especially in the heavy polluting enterprise, which has issued an early warning to companies and requires companies to participate in environmental protection and take the road of sustainable development. What's more, this paper also explains the reasons that companies participate in haze governance in some extent, and reveals the necessity of financial institutions to implement green credit policy. Through this article, we can get the following enlightenment. From one side, in order to improve debt financing capacity and realize the sustainable development, companies should undertake environment responsibility actively and improve the air quality proactively. Secondly, for financial institutions, the implementation of the green credit policy should be carried out effectively, the environmental performance of companies should be emphasized in the evaluation system, so that the companies with good environmental performance can reduce the credit constraint level, and play a role in the supervision of the bank's haze governance.

While this research provides a novel insight into the relationship between haze and the availability of company debt financing, it has limitations which future studies are encouraged to overcome. First, the paper is a new attempt to replace regional haze data as the company's sewage data, but this indicator also has limitations. Future research can consider using the environmental performance disclosed by each company as a more precise indicator of corporate sewage data. In addition, how to choose better control variables and how to innovate research methods are worthy of further study.

Author Contributions: Conceptualization and Design, B.L., P.G. and Y.Z.; methodology, software, validation and formal analysis, Y.Z. and P.G.; writing-review and editing, P.G. and Y.Z.; supervision, Y.Z.; project administration, B.L.; funding acquisition, B.L.

Funding: This work was supported by the National Natural Science Foundation of China (Grant No. 71603306), the Fundamental Research Funds for the Central Universities in China (Grant No. BUCTRC201808).

Conflicts of Interest: The authors declare no conflict of interest.

\section{References}

1. Tao, M.; Chen, L.; Ma, P.; Tao, J.; Wang, Z.; Xiong, X.; Zhang, M. Formation Process of the Widespread Extreme Haze Pollution over Northern China in January 2013: Implications for Regional Air Quality and Climate. Atmos. Environ. 2014, 98, 417-425. [CrossRef]

2. Wang, X.; Chen, J.; Sun, J.; Li, W.; Yang, L.; Wen, L.; Wang, W.; Wang, X.; Collett, J.L., Jr.; Shi, Y.; et al. Severe haze episodes and seriously polluted fog water in Ji'nan, China. Sci. Total Environ. 2014, 493, $133-137$. [CrossRef] [PubMed]

3. Chan, C.; Yao, X. Air pollution in mega cities in China. Atmos. Environ. 2008, 42, 1-42. [CrossRef]

4. Zhao, B.; Xu, J.; Hao, J. Impact of energy structure adjustment on air quality: A case study in Beijing, China. Front. Environ. Sci. Eng. China 2011, 5, 378-390. [CrossRef]

5. Wang, S.; Hao, J. Air quality management in China: Issues, challenges, and options. Environ. Sci. 2012, 24, 2-13. [CrossRef]

6. Shi, H.; Wang, Y.; Chen, J.; Huisingh, D. Preventing Amog Crises in China and Globally. J. Clean. Prod. 2016, 112, 1261-1271. [CrossRef]

7. Shao, M.; Tang, X.; Zhang, Y.; Li, W. City clusters in China: Air and surface water pollution. Front. Ecol. Environ. 2006, 4, 353-361. [CrossRef]

8. Parrish, D.; Zhu, T. Clean air for megacities. Science 2009, 326, 674-675. [CrossRef] [PubMed]

9. Clarkson, P.M.; Li, Y.; Richardson, G.D. The Market Valuation of Environmental Capital Expenditures by Pulp and Paper Companies. Account. Rev. 2004, 79, 329-353. [CrossRef]

10. Schneider, T.E. Is Environmental Performance a Determinant of Bond Pricing? Evidence from the US Pulp and Paper and Chemical Industries. Contemp. Account. Res. 2011, 28, 1537-1561. [CrossRef]

11. Liu, Y.; Liu, M. Does smog affect the earnings management of heavily polluting enterprises-Based on the investigation of the political cost hypothesis. Account. Res. 2015, 3, 26-33, 94.

12. Sheng, M.; Wang, S.; Zhang, C. "Smog” and corporate finance-Empirical evidence from heavily polluting listed companies. Econ. Rev. 2017, 28-39, 90.

13. Liu, X. Public Pressure, Property Rights and Corporate Financing Behavior-Based on the Research of “PM2.5 Explosion" Event. Econ. Sci. 2016, 2, 67-80. 
14. Brunekreef, B.; Holgate, S.T. Air Pollution and Health. Lancet 2002, 360, 1233-1242. [CrossRef]

15. Nel, A. Air pollution-related illness effects of particles. Science 2005, 308, 804-806. [CrossRef] [PubMed]

16. Li, W.; Zhou, S.; Wang, X.; Xu, Z.; Yuan, C.; Yu, Y.; Zhang, Q.; Wang, W. Integrated evaluation of aerosols from regional brown hazes over northern China in winter: Concentrations, sources, transformation, and mixing states. J. Geophys. Res. Atmos. 2011, 116, D09301. [CrossRef]

17. Kan, H.; Chen, R.; Tong, S. Ambient air pollution, climate change, and population health in China. Environ. Int. 2012, 42, 10-19. [CrossRef]

18. Dominici, F.; Greenstone, M.; Sunstein, C. Particulate matter matters. Science 2014, 344, 257-259. [CrossRef]

19. Li, W.; Shao, L.; Shi, Z.; Chen, J.; Yang, L.; Yuan, Q.; Yan, C.; Zhang, X.; Wang, Y.; Sun, J.; et al. Mixing state and hygroscopicity of dust and haze particles before leaving Asian continent. J. Geophys. Res. Atmos. 2014, 119, 1044-1059. [CrossRef]

20. Gehring, U.; Gruzieva, O.; Agius, R.M.; Beelen, R.; Custovic, A.; Cyrys, J.; Eeftens, M.; Flexeder, C.; Fuertes, E.; Heinrich, J.; et al. Air Pollution Exposure and Lung Function in Children: The ESCAPE Project. Environ. Health Perspect. 2013, 121, 1357-1364. [CrossRef]

21. Beelen, R.; Raaschou-Nielsen, O.; Stafoggia, M.; Andersen, Z.J.; Weinmayr, G.; Hoffmann, B.; Wolf, K.; Samoli, E.; Fischer, P.; Nieuwenhuijsen, M.; et al. Effects of Long-Term Exposure to Air Pollution on Natural-Cause Mortality: An Analysis of 22 European Cohorts within the Multicentre ESCAPE Project. Lancet 2014, 383, 785-795. [CrossRef]

22. Cesaroni, G.; Forastiere, F.; Stafoggia, M.; Andersen, Z.J.; Badaloni, C.; Beelen, R.; Caracciolo, B.; de Faire, U.; Erbel, R.; Eriksen, K.T.; et al. Long Term Exposure to Ambient Air Pollution and Incidenceof Acute Coronary Events: Prospective Cohort Study and Meta-Analysis in 11 European Cohorts from the ESCAPE Project. Br. Med. J. 2014, 348, 144. [CrossRef] [PubMed]

23. Fischer, P.H.; Marra, M.; Ameling, C.B.; Hoek, G.; Beelen, R.; de Hoogh, K.; Breugelmans, O.; Kruize, H.; Janssen, N.A.; Houthuijs, D. Air Pollution and Mortality in Seven Million Adults: The Dutch Environmental Longitudinal Study (DUELS). Environ. Health Perspect. 2015, 123, 697-704. [CrossRef] [PubMed]

24. Lundberg, A. Psychiatric Aspects of Air Pollution. Otolaryngol. Head Neck Surg. 1996, 114, 227-231. [CrossRef]

25. Cho, J.; Choi, Y.J.; Suh, M.; Sohn, J.; Kim, H.; Cho, S.K.; Ha, K.H.; Kim, C.; Shin, D.C. Air Pollution as a Risk Factor for Depressive Episode in Patients with Cardiovascular Disease, Diabetes Mellitus, or Asthma. J. Affect. Disord. 2014, 157, 45-51. [CrossRef] [PubMed]

26. Pope, C.A., 3rd; Burnett, R.T.; Thun, M.J.; Calle, E.E.; Krewski, D.; Ito, K.; Thurston, G.D. Lung cancer, cardiopulmonary mortality, and long-term exposure to fine particulate air pollution. J. Am. Med Assoc. 2002, 287, 1132-1141. [CrossRef]

27. Grossman, G.M.; Krueger, A.B. Environmental Impacts of a North American Free Trade Agreement; Social Science Electronic Publishing: London, UK, 1991; pp. 223-250.

28. Stern, D.I. The Rise and Fall of the Environmental Kuznets Curve. World Dev. 2004, 32, 1419-1439. [CrossRef]

29. Dinda, S. Environmental Kuznets Curve Hypothesis: A Survey. Ecol. Econ. 2004, 49, 431-455. [CrossRef]

30. Fotourehchi, Z. Health Effects of Air Pollution: An Empirical Analysis for Developing Countries. Atmos. Pollut. Res. 2016, 7, 201-206. [CrossRef]

31. Shen, H.; Feng, J. Public opinion supervision, government supervision and corporate environmental information disclosure. Account. Res. 2012, 2, 72-78, 97.

32. Monks, P.S.; Archibald, A.T.; Colette, A.; Cooper, O.; Coyle, M.; Derwent, R.; Fowler, D.; Granier, C.; Law, K.S.; Mills, G.E.; et al. Tropospheric ozone and its precursors from the urban to the global scale from air quality to short-lived climate forcer. Atmos. Chem. Phys. 2015, 15, 8889-8973. [CrossRef]

33. Parrish, D.D.; Xu, J.; Croes, B.; Shao, M. Air quality improvement in Los Angeles-Perspectives for developing cities. Front. Environ. Sci. Eng. 2016, 10, 69-81. [CrossRef]

34. Darnall, N.; Jolley, J.; Ytterhus, B. Understanding the relationship between a facility's environmental and financial performance. Corp. Behav. Environ. Policy 2007, 5, 213-259.

35. Chen, S.; Sun, Z.; Tang, S.; Dong, H.Q. Government intervention and investment efficiency: Evidence from China. J. Corp. Financ. 2011, 17, 259-271. [CrossRef]

36. Xiong, Y.; Xu, X. The influence of environmental regulation on China's foreign direct investment: Evidence on the analysis of paneldata. Econ. Rev. 2007, 2, 122-125.

37. Chava, S. Environmental externalities and cost of capital. Manag. Sci. 2014, 60, 2223-2247. [CrossRef] 
38. Mohr, R.D.; Saha, S. Distribution of Environmental Costs and Benefits, Additional Distortions, and the Porter Hypothesis. Land Econ. 2008, 84, 689-700. [CrossRef]

39. Pil, F.K.; Rothenberg, S. Environmental performance as a driver of superior quality. POMS 2003, 12, 404-415. [CrossRef]

40. Lee, S.-Y.; Klassen, R.D. Drivers and enablers that foster environmental management capabilities in smalland medium-sized suppliers in supply chains. POMS 2008, 17, 573-586. [CrossRef]

41. Zorzini, M.; Hendry, L.C.; Huq, F.A.; Stevenson, M. Socially responsible sourcing: Reviewing the literature and its use of theory. Int. J. Oper. Prod. Manag. 2015, 35, 60-109. [CrossRef]

42. Dey, P.K.; Petridis, N.E.; Petridis, K.; Malesios, C.; Noxon, J.D.; Ghosh, S.K. Environmental management and corporate social responsibility practices of small and medium-sized enterprises. J. Clean. Prod. 2018, 195, 687-702. [CrossRef]

43. Zhang, H.; Wang, S.; Hao, J.; Wang, X.; Wang, S.; Chai, F.; Li, M. Air pollution and control action in Beijing. J. Clean. Prod. 2015, 112, 1519-1527. [CrossRef]

44. Freedman, P.L.; Click, R.W. Banks That Don't Lend? Unlocking Credit to Spur Growth in Developing Countries. Dev. Policy Rev. 2006, 24, 279-302. [CrossRef]

45. Banerjee, T.L. Creditor Control Rights, State of Nature Verification, and Financial Reporting Conservatism. J. Account. Econ. 2013, 55, 1-22.

46. Stiglitz., J.E.; Weiss, A. Credit Rationing in Market with Imperfect Information. Am. Econ. Rev. 1981, 71, 393-410.

47. Ma, J.; Wu, B. Interest Rate Floating Policy, Differential Pricing Strategy and Credit Rationing of Financial Institutions to Farmers. Financ. Res. 2012, 4, 155-168.

48. Shen, X. Bank Risk Identification, Government Subsidy and Corporate Debt Financing Cost—An Empirical Test Based on Company Data of Shanghai and Shenzhen Stock Exchanges from 2007 to 2012. Financ. Trade Econ. 2014, 9, 62-71.

49. Menz Garcialara, J.M.; Garcia Osma, B.; Penalva, F. Accounting Conservatism and Corporate Governance. Rev. Account. Stud. 2009, 14, 161-201. [CrossRef]

50. Campbell, K.; Sefcik, S.E.; Soderstrom, N.S. Disclosure of Private Information and Reduction of Uncertainty: Environmental Liabilities in the Chemical Industry. Rev. Quant. Financ. Account. 2003, 21, 349-378. [CrossRef]

51. Cormier, D.; Magnan, M. Investors' Assessment of Implicit Environmental Liabilities: An Empirical Investigation. J. Account. Public Policy 1997, 16, 215-241. [CrossRef]

52. Green, A. You Can't Pay them Enough: Subsidies, Environmental Law, and Social Norms. Harv. Environ. Law Rev. 2006, 3, 407-426.

53. Coffee, J.C., Jr. Do Norms Matter? A Cross-Country Evaluation. Univ. Pa. Law Rev. 2001, 149, $2151-2177$. [CrossRef]

54. Levy, T.; Yagil, J. Air Pollution and Stock Returns in the US. J. Econ. Psychol. 2011, 32, 374-383. [CrossRef]

55. Lian, L. Does Green Credit Influence Corporate Debt Financing Costs?-Based on Comparative Study of Green Enterprises and “Two High" Enterprises. Stud. Financ. Econ. 2015, 5, 83-93.

56. Ackerman, F.; Heinzerling, L. Pricing the Priceless: Cost-Benefit Analysis of Environmental Protection. Univ. Pa. Law Rev. 2002, 150, 1553-1584. [CrossRef]

57. Sean, C. The Relationship between Firm Investment and Financial Status. J. Financ. 1999, 54, 673-692.

58. Frank, M.Z.; Goyal, V.K. Testing the pecking order theory of capital structure. J. Financ. Econ. 2003, 67, 217-248. [CrossRef]

59. Seifert, B.; Gonenc, H. The international evidence on the pecking order hypothesis. J. Multinatl. Financ. Manag. 2008, 18, 244-260. [CrossRef]

60. Lennox, C.; Wu, X.; Zhang, T. The effect of audit adjustments on earnings quality: Evidence from China. J. Account. Econ. 2016, 61, 545-562. [CrossRef]

61. Lim, C.Y.; Wang, J.; Zeng, C. China's "Mercantilist" government subsidies, the cost of debt and company performance. J. Bank. Financ. 2018, 86, 37-52. [CrossRef]

(C) 2019 by the authors. Licensee MDPI, Basel, Switzerland. This article is an open access article distributed under the terms and conditions of the Creative Commons Attribution (CC BY) license (http:// creativecommons.org/licenses/by/4.0/). 